\title{
A key to species of the tribe Scolytini Latreille, 1804 (Coleoptera: Curculionidae: Scolytinae) from Russia and adjacent countries
}

\author{
Определительные таблиџы видов трибы Scolytini Latreille, 1804 \\ (Coleoptera: Curculionidae: Scolytinae) России и сопредельных стран
}

\author{
A.V. Petrov', M.Yu. Mandelshtam², R.A. Beaver ${ }^{3}$ \\ А.В. Петров ${ }^{1}$, М.Ю. Мандельштам², Р.А. Бивер ${ }^{3}$
}

\footnotetext{
Institute of Forest Science RAS, Sovetskaya st. 21, Uspenskoe, Moscow Region 143030, Russia. E-mail: hylesinus@list.ru

2 St. Petersburg State Forest Technical University named after S.M. Kirov, Institutskii per. 5, St. Petersburg 194021, Russia. E-mail: michail@MM13666.spb.edu

3 161/2 Mu 5, Soi Wat Pranon, T. Donkaew, A. Maerim, Chiangmai 50180, Thailand. E-mail: rogerbeaver6@gmail.com

1 Институт лесоведения Российской академии наук, с. Успенское, ул. Советская, д. 21, 143030 Московская обл., Россия.

2 Санкт-Петербургский государственный лесотехнический университет им. С.М. Кирова, Институтский пер., д. 5, 194021 СанктПетербург, Россия.
}

KEY WORDS: Coleoptera, Curculionidae, Scolytinae, Scolytus, bark beetles, taxonomy, Russia, countries of the former USSR.

КЛЮЧЕВЫЕ СЛОВА: Coleoptera, Curculionidae, Scolytinae, Scolytus, короеды, систематика, Россия, страны бывшего СССР.

ABSTRACT. Original keys for identification of males and females of all Scolytus Geoffroy, 1762 species from the territory of the former USSR based on features of external morphology are developed. An annotated list of species provides data on synonymy, geographic distribution and host-plants of all Scolytus species of the Russian fauna.

РЕЗЮМЕ. Составлены оригинальные определительные таблицы для идентификации самцов и самок всех видов рода Scolytus Geoffroy, 1762 фауны бывшего СССР по признакам внешней морфологии. В аннотированном списке видов приведены данные по синонимии, географическому распространению и кормовым растениям видов рода Scolytus фауны России.

The tribe Scolytini Latreille, 1804, includes 6 genera and more than 210 recent species. Of these genera only the genus Scolytus Geoffroy, 1762 is native in the Palaearctic region, including Russia, and is the subject of this paper. The world fauna of the genus Scolytus currently includes 126 recent and 4 fossil species. Fifty seven Scolytus species occur in the Palaearctic [Butovitsch, 1929; Knížek, 2011; Krivolutskaya, 1958, 1996; Kurentsov, 1941; Mandelshtam, Isaev, 2006; Mandelshtam, Petrov, 2016; Michalski, 1973; Nikulina et al., 2015; Petrov, 2013; Pfeffer, 1995; Schedl, 1948; Smith,
Hulcr, 2015; Sokanovskiy, 1954, 1958, 1960, 1966; Spessivtsev, 1925; Stark, 1952; Wood, Bright, 1992].

The characteristic features of the genus Scolytus include the following: 1) a deep impression between the elytral bases with the scutellum immersed in it; 2) lateral margins of elytra straight, smooth, without a deep notch; 3) elytra with weakly developed apical declivity; 4) in the great majority of species abdomen in profile obliquely ascending from the first sternite towards apex of fifth sternite at an angle close to $45^{\circ}$; 5 ) eighth tergite at the interior margin with a broad and deep central notch; 6) labium with narrow mentum, ligula on mentum not developed; 7) proventriculus with a deep cleft, broadly dividing the two halves of the posterior membrane, and extending to the base of the anterior membrane; 8) male genitalia with an extended median lobe and short apophyses (rarely the length of the apophyses subequal to median lobe length (Fig. 1); median lobe flat or arcuate, straight (Figs 24) or sickle-shaped (Figs 6-9), lateral folds thick and arcuate, lateral and apical margins with greater sclerotization, apex round (Fig. 12) or truncate (Figs 9-10), in some species the apical third with sclerotized processes (Figs 8-10) or pointed tubercles (Figs 13-14); tegmen fork-shaped, ventral side elongated proximally; spicule shorter than aedeagus, sickle-shaped.

All Palearctic Scolytus species are monogamous except for one species, Scolytus ensifer Eichhoff, 1881,

How to cite this article: Petrov A.V., Mandelshtam M.Yu., Beaver R.A. 2019. A key to species of the tribe Scolytini Latreille, 1804 (Coleoptera: Curculionidae: Scolytinae) from Russia and adjacent countries // Russian Entomol. J. Vol.28. No.3. P.286-302. doi: 10.15298/rusentj.28.3.08 
which is bigamous or polygamous. All species are phloeophagous. Palearctic species breed in deciduous host trees including Betulaceae, Elaeagnaceae, Fabaceae, Fagaceae, Juglandaceae, Oleaceae, Ulmaceae, Rosaceae and two species attack conifers (Pinaceae) (Scolytus major Stebbing, 1903 - host tree Cedrus and S. morawitzi Semenov, 1902 - host tree Larix) [Krivolutskaya, 1958, 1996; Kurentsov, 1941; Petrov, 2013; Pfeffer,
1995; Smith, Hulcr, 2015; Wood, Bright, 1992].

Many Scolytus species are of economic significance being vectors for fungal and bacterial pathogens, causing tree diseases, e.g. devastating Dutch elm disease [Smith, Hulcr, 2015; Petrov, Dostavalov, 2015], and therefore the correct Scolytus species identification is of importance for forests entomologists, making publication of the current revision relevant.
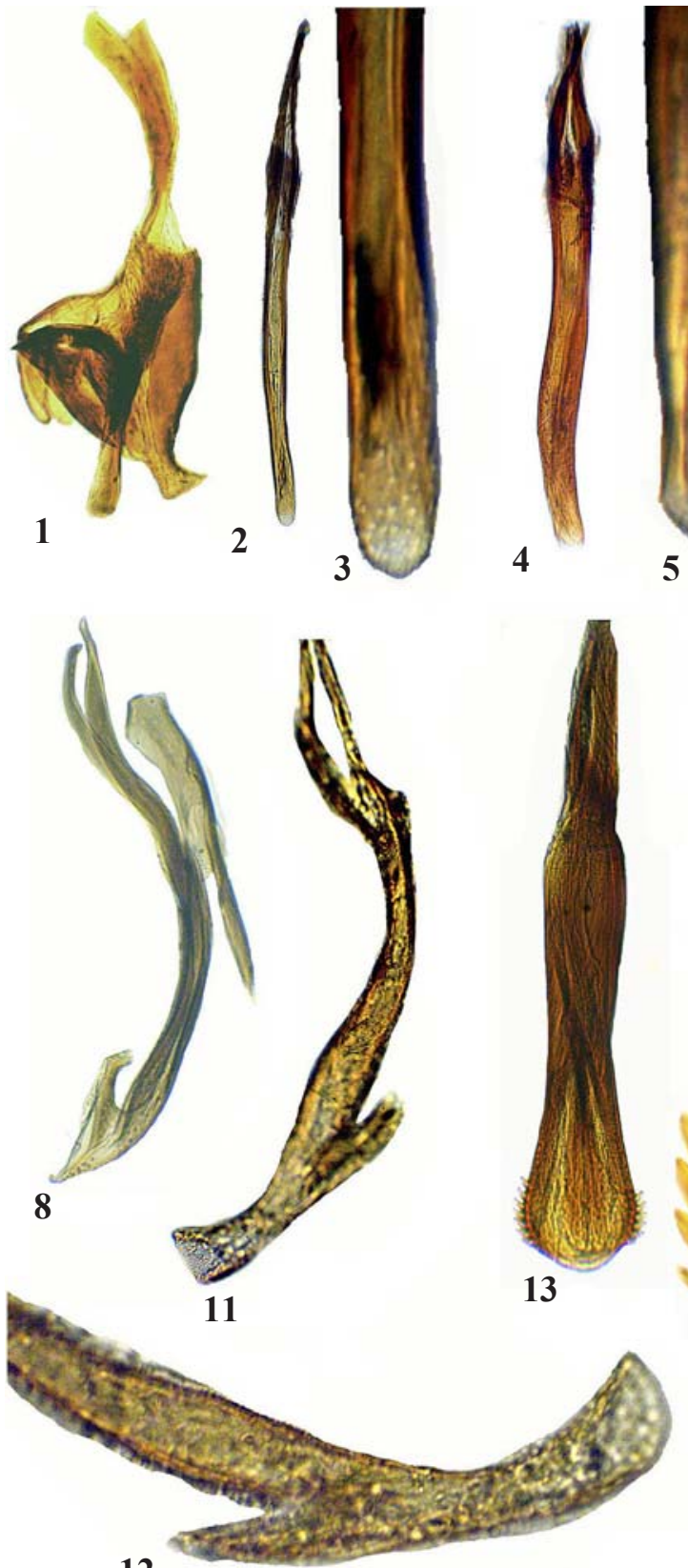

12

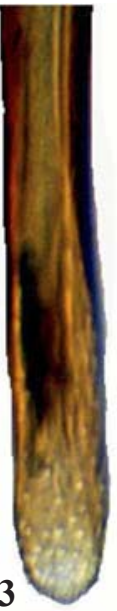

4

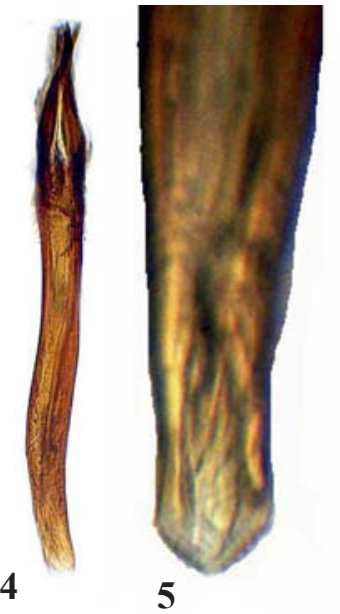

6
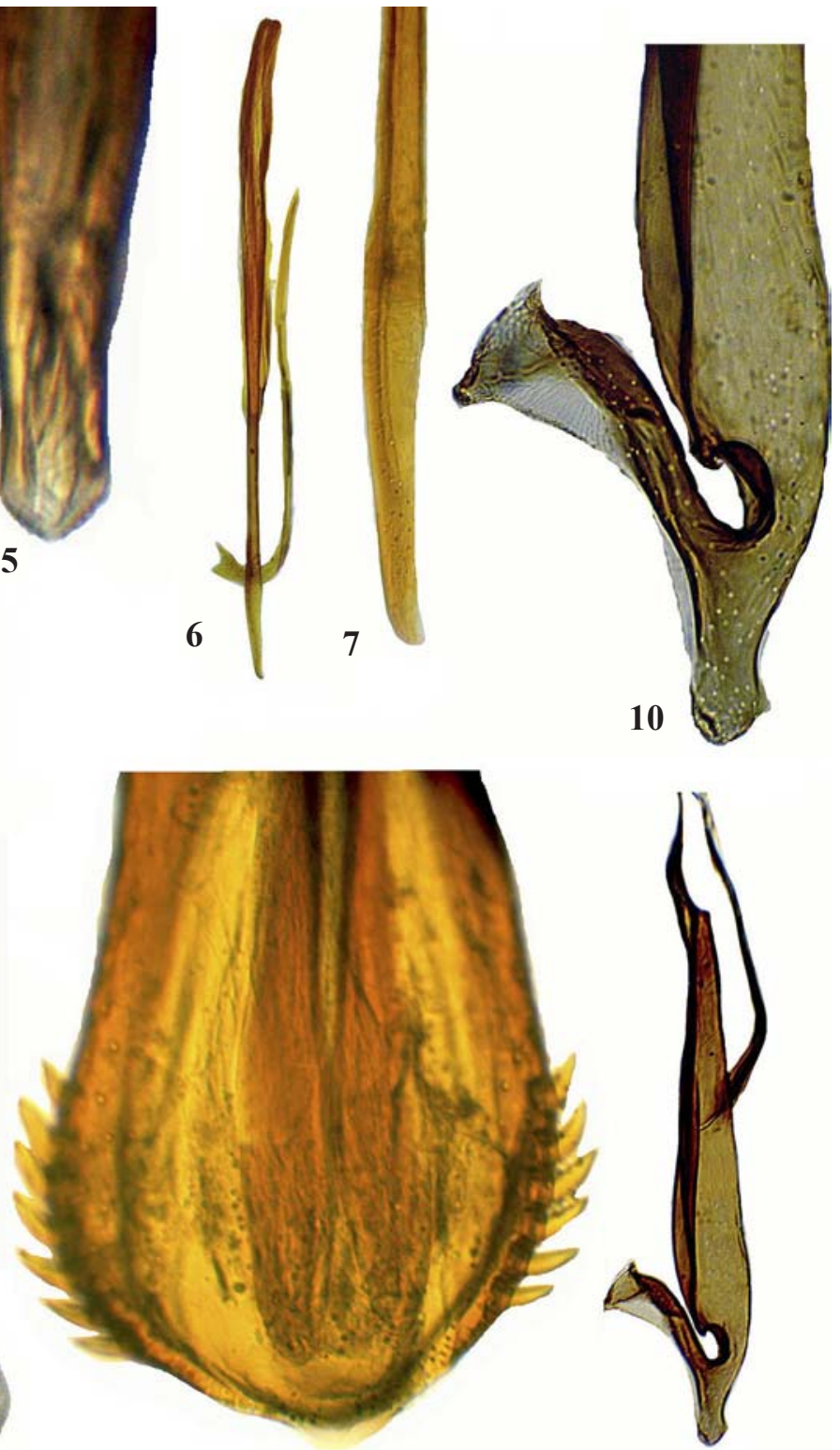

14

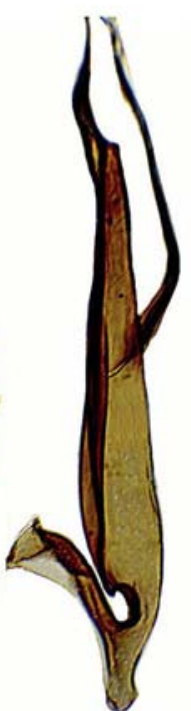

9

Figs 1-14. Male genitalia of the genus Scolytus: $1-$ S. rugulosus; 2-3 - S. schevyrewi; 4-5 - S. transcaspicus; 6-7 - S. koltzei; $8-$ S. japonicus; 9-10-S. koenigi; 11-12-S. zaitzevi; 13-14-S. tadzhikistanicus; 1, 8-12 - lateral view; 2-7, 13-14 - dorsal view; $3,5,7,10,12,14$ - apical third of median lobe.

Рис. 1-14. Гениталии самцов короедов рода Scolytus: $1-$ S. rugulosus; 2-3 - S. schevyrewi; 4-5 - S. transcaspicus; 6-7 - S. koltzei; $8-$ S. japonicus; 9-10-S. koenigi; 11-12-S. zaitzevi; 13-14-S. tadzhikistanicus; 1, 8-12 - сбоку; 2-7, 13-14- сверху; $3,5,7,10,12,14$ - вершина трубки пениса. 


\section{Material and methods}

Specimens used in the present work were collected by the authors from 1975 to 2019 in the forests of the Russian Federation, including European part of Russia (Belgorod, Ivanovo, Kaliningrad, Kaluga, Kursk, Leningrad, Moscow, Tambov, Tula, Tver, Vladimir, Vologda, Voronezh, Yaroslavl Provinces), Volga Region (Astrakhan and Volgograd Provinces), Republic of Crimea, Republic of Karelia, North and North-West Caucasus (Krasnodar Terr., Adygeya Republic, Dagestan Republic), forests of Siberian Federal district (Buryatia Republic, Chita Province), Far-East (Primorsk Terr., Sakhalin Island, Kunashir Island) and elsewhere. Outside Russia Scolytus beetles were sampled in Austria, Azerbaijan, Georgia, Kazakhstan, Kirgizstan, Tajikistan, Turkmenistan, Uzbekistan, Ukraine. Also specimens deposited in the Zoological Museum of Russian Academy of Sciences (St. Petersburg), Zoological Museum of Moscow University (Moscow), Natural History Museum (London), Naturhistorisches Museum Wien (Vienna), United States National Museum of Natural History (Washington) were examined.

Data about distribution were taken principally from Knížek [2011] and data about host plants from Pfeffer [1995] and Krivolutskaya [1996], but many unlisted sources were used as well as the authors' own field observations.

Photographs of beetles were taken using a Canon 50D camera and macro lens MP-e65, and processed using the program CombineZP.

\section{Results}

The fauna of Russia and adjacent countries (within the borders of the former USSR) includes 40 Scolytus species. A key to all Russian Scolytus species is provided in the current paper with the exception of $S$. nunbergi Michalski, 1964 the status of which as a separate species will be clarified in the future.

Key to the SCOLYTUS SPECIES OF RUSSiA AND NEIGHBORING COUNTRIES.

1. One or several abdominal sternites (ventrites) with a distinct denticle or separate denticles or with thickening and elevation at posterior margins of ventrites 3, 4 or both (Figs 32, 64, 66, 75, 78) ened and elevated posterior margins of ventrites 3-4 (Figs $71,82-91)$

2. Ventrite 2 with distinct median denticle or tubercle (Figs $35-36,43,52)$

- Ventrite 2 without median denticle or tubercle (Figs 64 66) .. 28

3. Median denticle on ventrite 2 is situated in the middle of ventrite base; ventrite 2 steeply ascending, nearly vertical, forming an angle of $70-85^{\circ}$ with the surface of ventrite 1 (Figs 27, 29-32, 35)

- Median denticle on ventrite 2 is not situated at the extreme ventrite base, but shifted towards centre or posterior margin of ventrite; ventrite 2 gradually ascending forming a smooth arc with ventrite 1 in profile (Figs 52-55) 24

4. Apex of the ventrite 2 denticle is situated at the same horizontal level as its base or slightly elevated relative to it; punctures on elytral striae distinctly larger than punctures on interstriae ..................................................... 5

- Apex of the ventrite 2 denticle is situated below its base, denticle directed obliquely downwards; punctures on elytral striae and interstriae are approximately of the same size ......... 21

5. Median part of pronotal base with triangular projection directed towards scutellum and scutellar impression (Figs $26,29)$, length of pronotum with prescutellar projection almost equal to elytral length; frons in male flat, with long bristle-shaped setae laterally, ventrite 2 with short tubercle (Fig. 27); female with weakly convex frons, with long thin hair-like setae over its entire surface, ventrite 2 with tiny tubercle (Fig. 28); stout beetles, length to width ratio $2.1 ; 2.0-2.8 \mathrm{~mm}$......... S. butovitschi (male and female)

- Pronotal base straight, without triangular projection directed backwards (Fig. 33)

6. Lateral sides of ventrites 3 and 4 with small acute denticles (Figs 30-32, 34) ...................................................... 7

- Lateral sides of ventrites 3 and 4 without small acute denticles (Figs 36, 43) .............................................. 9

7. Elytral apices with numerous long setae forming sparse brush-like structures laterally; abdomen with long bristleshaped setae; frons in male with short sparse hair-like setae (Fig. 30), in female with dense thin pale hair-like setae; $2.2-2.8 \mathrm{~mm}$........ S. orientalis (male and female)

- Elytral apices and abdomen with short and sparse hair-like setae; frons in males with dense long hair-like setae (Figs $31,33)$

8. Anterior margin of ventrite 2 with blunt, dorsoventrally flat, wide horizontal process (Figs 34-35); in male posterior margin of ventrite 3 with obtuse median tubercle, ventrite 4 thickened in the middle, sometimes this thickening triangularly raised (Fig. 35); frons in female convex, with short pale hair-like setae, no denticles present on ventrites 3 and 4; 2.5-3.8 $\mathrm{mm}$ (Fig. 33).

S. ecksteini (male and female)

- Process on anterior margin of ventrite 2 with narrow base and middle, may be slightly expanded at the apex, nearly circular in cross-section; in male posterior margin of ventrite 3 with obtuse median denticle (Fig. 32), median parts of posterior margins of ventrites 3 and 4 in males slightly thickened (sometimes thickened areas may bear tiny tubercles); frons in females with sparse short hair-like setae, no denticles present on ventrites 3 and 4; 2.3-4.1 mm (Figs 15, 31-32) ..................... S. multistriatus (male and female)

9. Median part of the suture on the posterior margin of ventrite 4 thickened and strongly elevated relative to the base of the next ventrite (Figs 36, 38, 43) ................ 10

- Suture on the posterior margin of ventrite 4 not thickened, but only weakly elevated relative to the base of the next ventrite .................................................... 13

10. Ventrite 2 process long, two times greater than the width of sternite 1, with the apex bent upwards; posterior margin of ventrite 4 elevated as triangular protrusion (Figs 36, 38, 40)

- Ventrite 2 median denticle short, its length less than width of ventrite 1 ; in males, elevated suture at posterior margin of ventrite 4 rounded in the median part .................. 12

11. Frons flat or slightly depressed (shape variable), its lateral edges not keeled, lateral areas of frons with abundant long pale hair-like setae inwardly curved; $1.6-3.2 \mathrm{~mm}$

S. ensifer (male) 


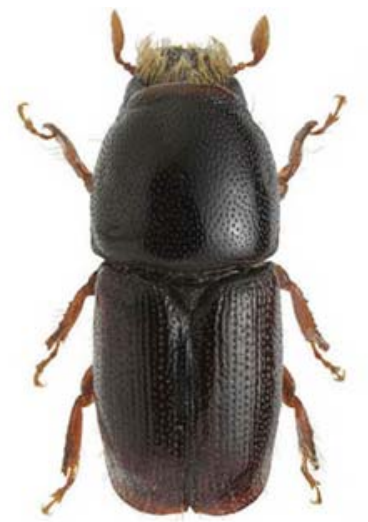

15

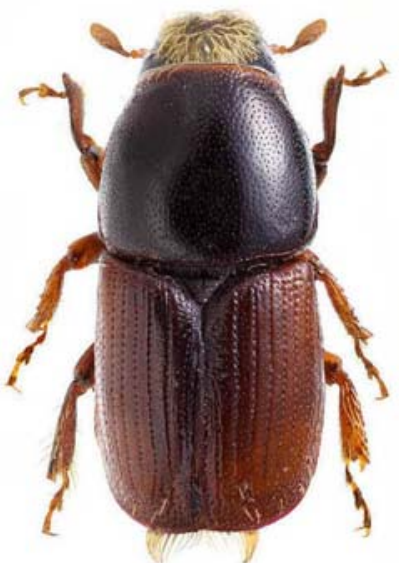

19

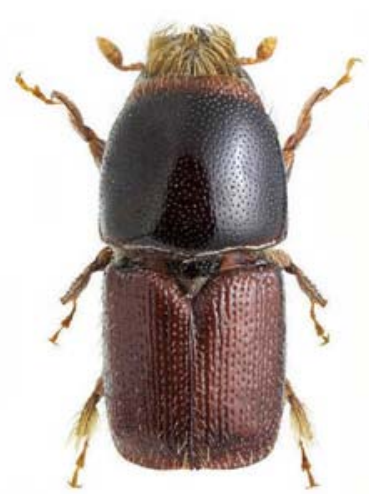

16

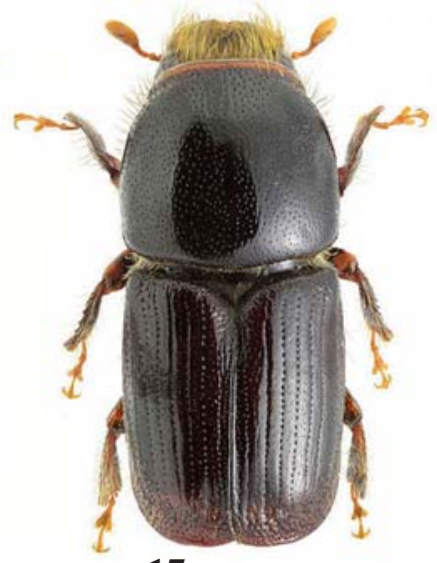

17

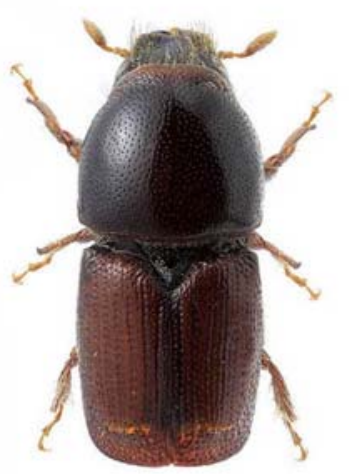

18

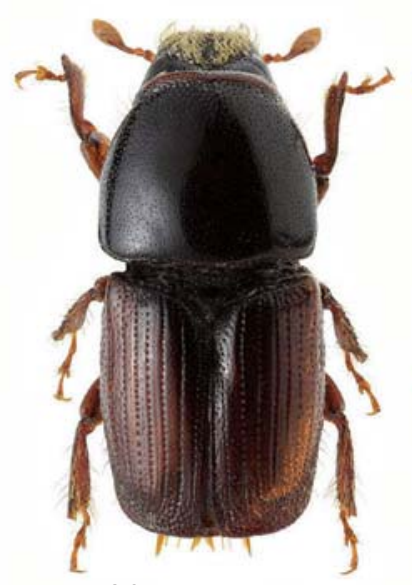

20

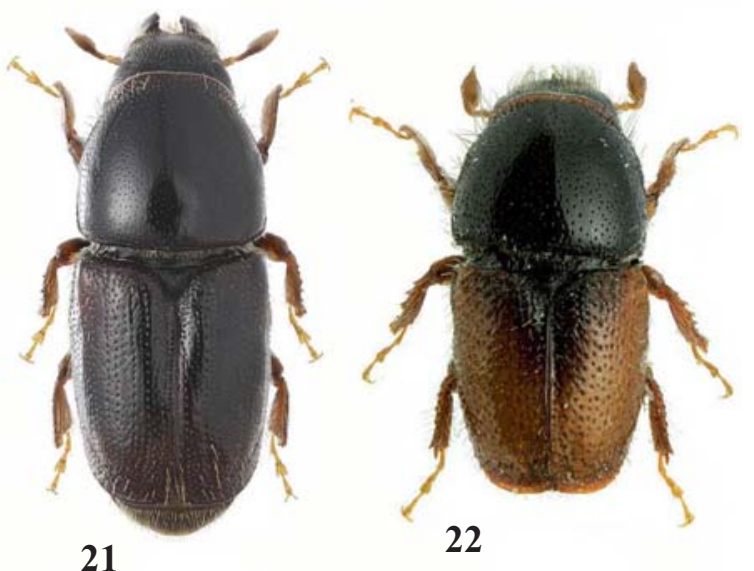

21

22

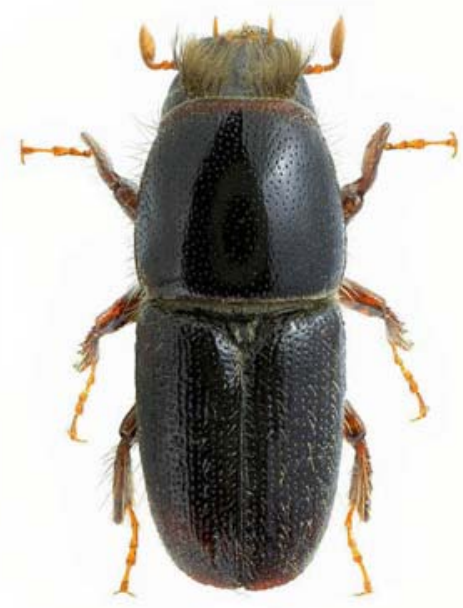

23

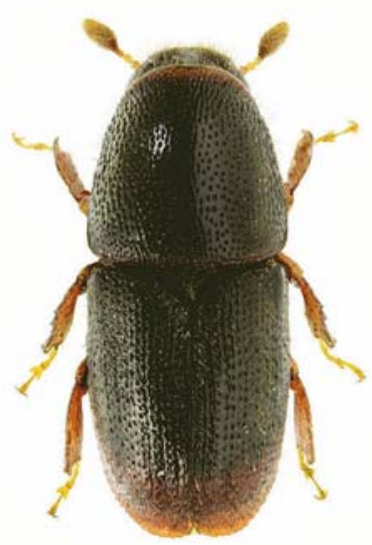

24

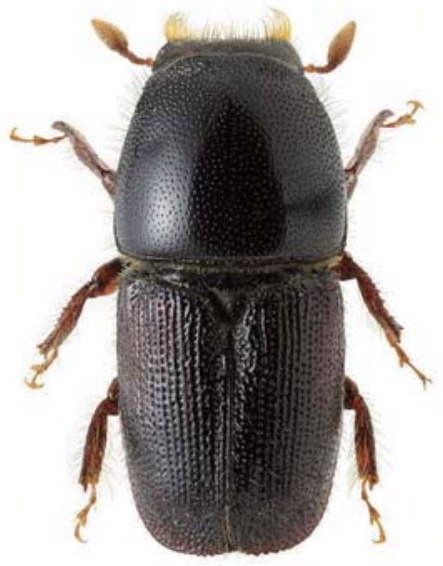

25

Figs 15-25. Habitus of bark beetles of the genus Scolytus: 15 - S. multistriatus, male; 16 - S. ensifer, male; 17 - S. ratzeburgii, male; 18 - S. pygmaeus, male; $19-$ S. eichhoffi, male; $20-$ S. sulcifrons, male; $21-$ S. mali, female (Photograph from www.zin.ru\AnimalialColeoptera Author Kirill V. Makarov. Used with permission as indicated on website); $22-S$. gretschkini, female; 23 - S. tadzhikistanicus, male; $24-$ S. rugulosus, female; $25-$ S. koenigi, male.

Рис. 15-25. Габитус короедов рода Scolytus: $15-$ S. multistriatus, самец; $16-$ S. ensifer, самец; $17-$ S. ratzeburgii, самец; $18-$ S. pygmaeus, самец; 19 - S. eichhoffi, самец; 20-S. sulcifrons, самец; 21-S. mali, самка (Фотография с www.zin.ru $\backslash$ Animalia $\backslash$ Coleoptera. Автор К.В. Макаров. Используется с разрешения автора); $22-$ S. gretschkini, самка; 23 - S. tadzhikistanicus, самец; $24-S$. rugulosus, самка; $25-S$. koenigi, самец. 


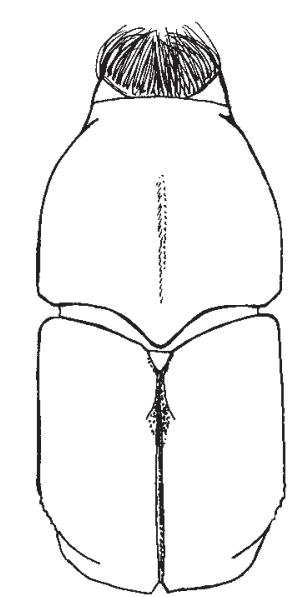

26

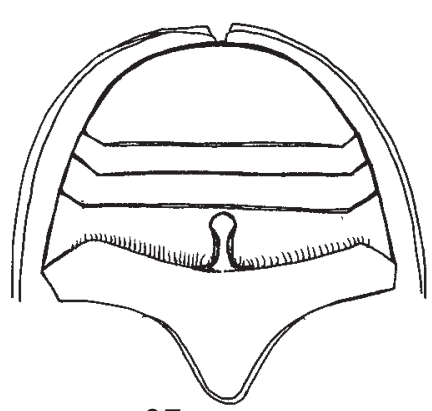

27
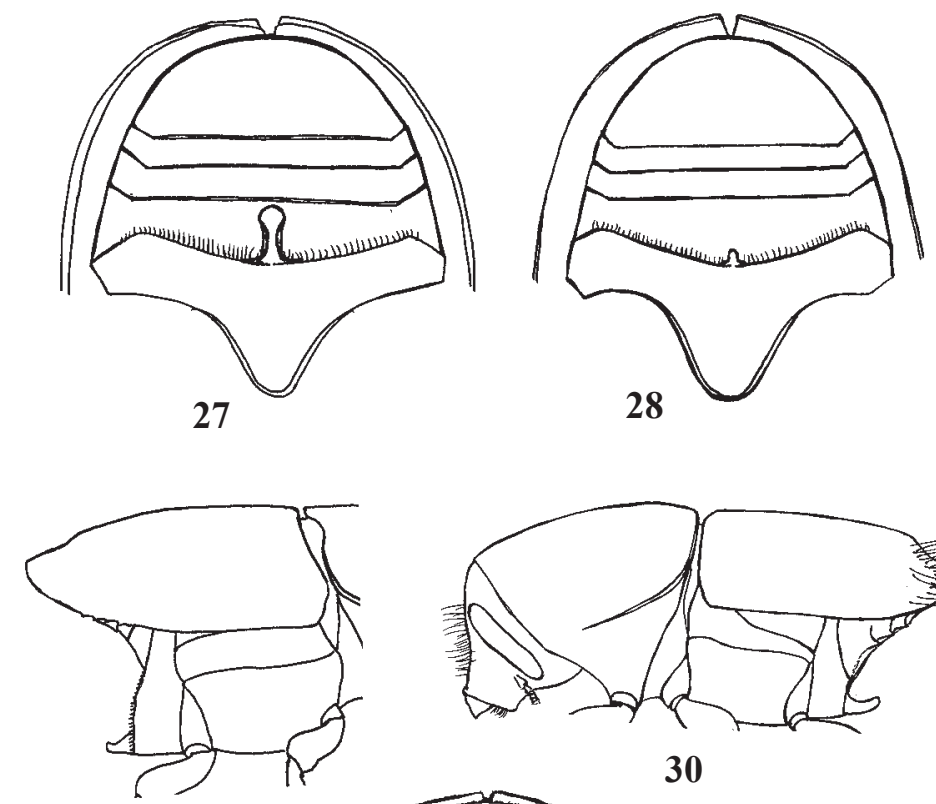

29

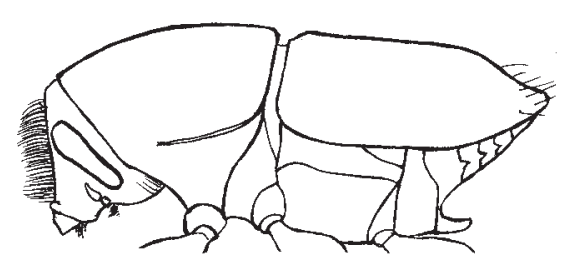

31

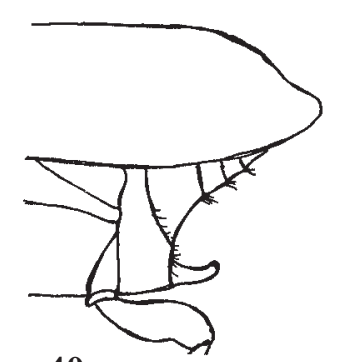

40

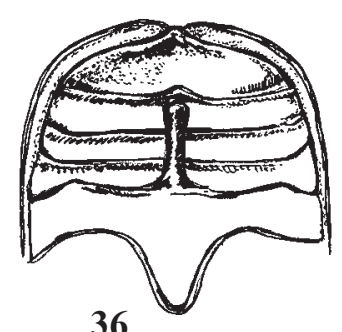

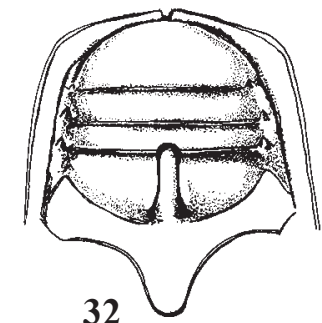

32

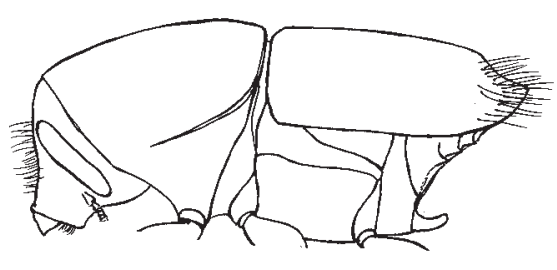

30

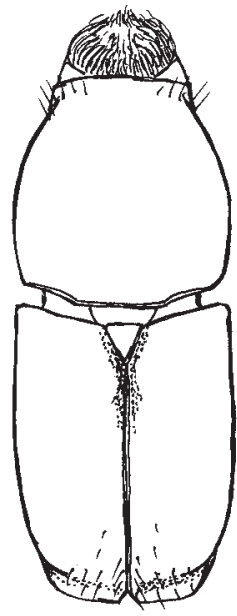

33
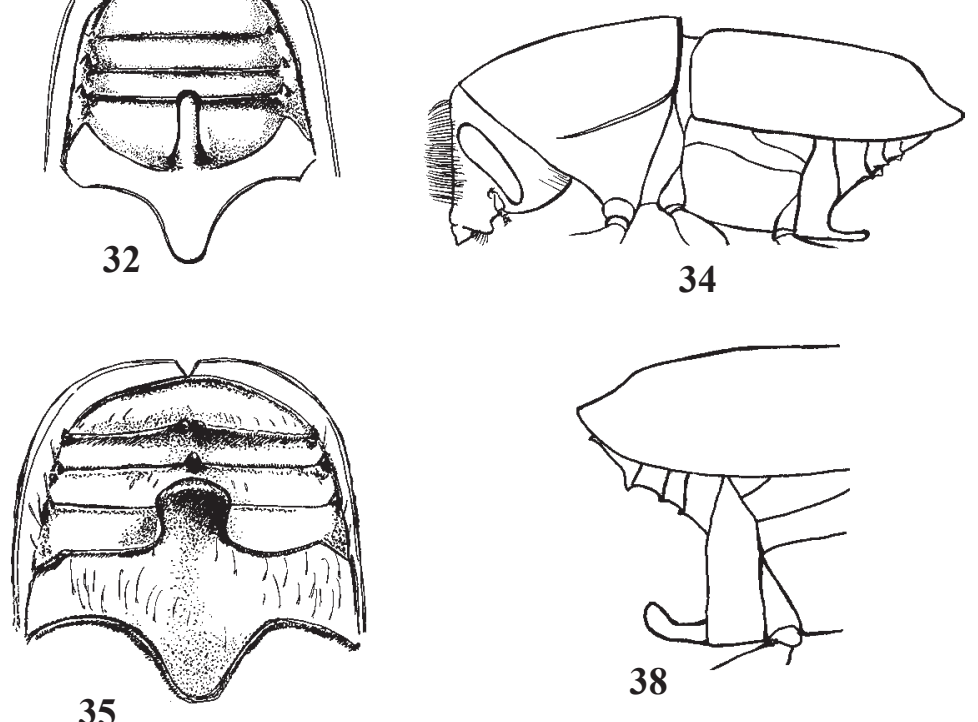

35

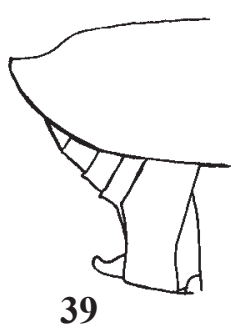

37

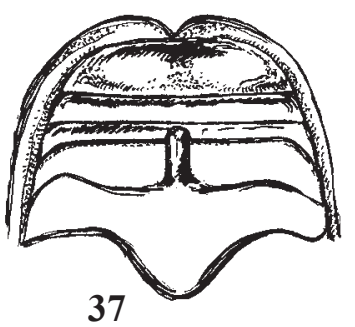

Figs 26-40. Habitus and details of bark beetles of the genus Scolytus: 26-29-S. butovitschi; $30-$ S. orientalis; 31-32 - S. multistriatus; 33-35-S. ecksteini; 36-39-S. ensifer; 40 - S. varshalovitchi; 26-27, 29-36, 38, 40 - males; 28, 37, 39- females; 26, 33 - habitus, dorsal view; 29-31, 34, 38-40 - lateral view; 27-28, 32, 35-37 - abdomen.

Рис. 26-40. Габитус и детали строения короедов рода Scolytus: 26-29-S. butovitschi; 30 - S. orientalis; 31-32 - S. multistriatus; 33-35 - S. ecksteini; 36-39 - S. ensifer; 40 - S. varshalovitchi; 26-27, 29-36, 38, 40 - самцы; 28, 37, 39 - самки; 26, 33 - сверху; 29-31, 34, 38-40 - сбоку; 27-28, 32, 35-37 - брюшко. 
- Frons depressed, lateral edges of depression keeled, elevated; frons similar; $1.6-3.2 \mathrm{~mm}$ S. varshalovitchi (male)

12. Apex of the ventrite 2 denticle with distinct median impression, surrounded by inverted horseshoe-shaped lateral edges; median parts of sutures on posterior margins of ventrites 3 and 4 thickened (Fig. 41); punctures on elytral striae shallow, slightly elongate, elliptical; apices of elytra with erect acutely pointed setae; $2.0-2.3 \mathrm{~mm}$

S. kononovi (male)

- Apex of the ventrite 2 denticle without median impression, evenly obtusely rounded (Figs 42-43); punctures on elytral striae deeper, round; apices of elytra with indistinct sparse and short setae; frons in males flat, lateral areas with abundant long hair-like setae, in females frons convex, with short sparse hair-like setae, suture on posterior margin evenly weakly raised; $1.8-2.5 \mathrm{~mm}$

S. semenovi (male and female)

13. Frons flat or depressed, lateral areas with long bristle-like setae, process of ventrite 2 with widened and upturned apex, bearing small depression on top; males ............ 14

- Frons convex, entire surface with thin pale hair-like setae, denticle of ventrite 2 laterally compressed; females ... 15

14. Frons depressed; elytral interstriae 9 convex, with small denticles; ventrite 2 with large dorsoventrally flat process, its length equal to or greater than width of ventrite 1 ; elytra and abdomen with appressed short hair-like setae; 3.3$5.3 \mathrm{~mm}$...... S. claviger (male)

- Frons flat; elytral interstriae 9 flat without acute denticles; ventrite 2 with shorter process, its length shorter than width of ventrite 1; elytral apices and ventrites with abundant long hair-like setae (Fig. 44); 2.9-3.4 mm; ... .. S. pubescens (male)

15 . Denticle of ventrite 2 with obtuse, vertically cut or rounded apex .

- Ventrite 2 with short keel-like denti denticle with acute and elevated apex ...................... 18

16 . Ventrite 2 with large, laterally flattened denticle directed horizontally, almost parallel to the longitudinal body axis, its lower edge slightly rounded, base of denticle narrow, laterally compressed, denticle without strong widening towards apex and without apical notch, apex rounded, denticle length greater than half of ventrite 1 width; ventrite 2 with abundant erect hair-like setae of the same length as the denticle (Figs 46-47); frons evenly covered with thin short hair-like setae; $3.4-4.1 \mathrm{~mm}$

S. koltzei (female)

- Ventrite 2 with small denticle vertically cut at apex 17

17. Punctures on elytral striae deeper, rounded; elytral apices

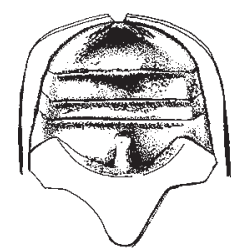

41

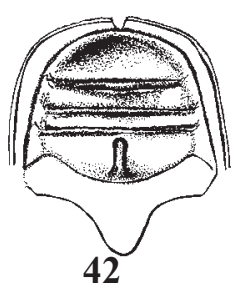

42

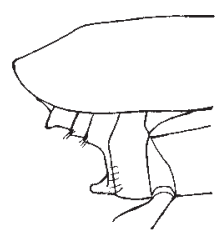

43

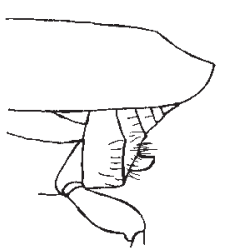

47

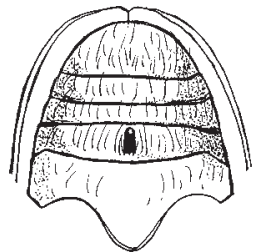

50

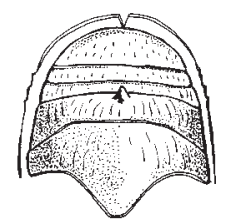

55
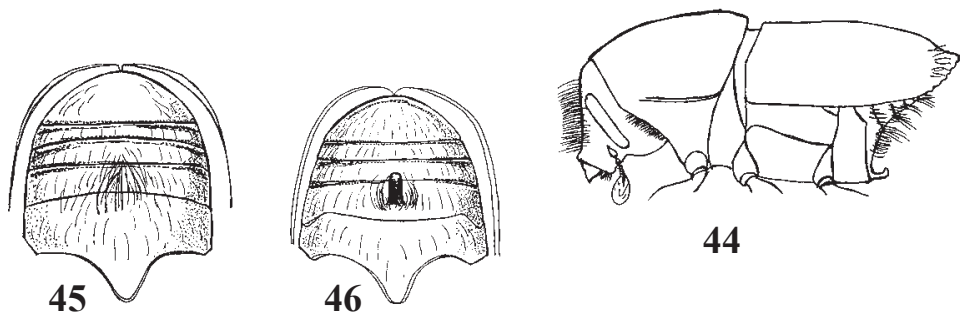

44

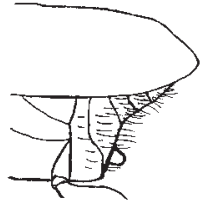

51

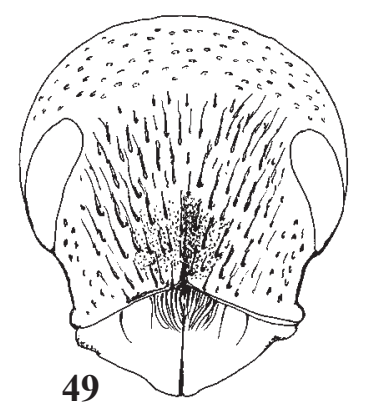

49

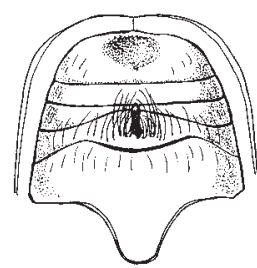

53

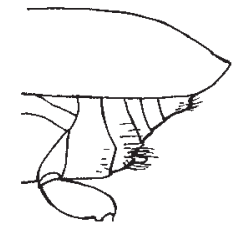

54
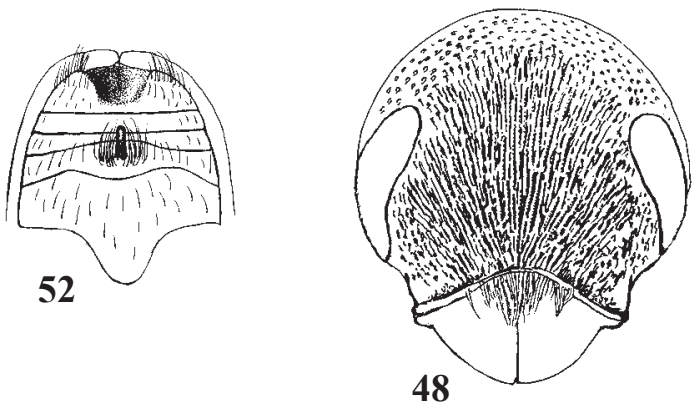

Figs 41-55. Habitus and details of bark beetles of the genus Scolytus: $41-$ S. kononovi; $42-43-$ S. semenovi; $44-S$. pubescens; $45-$ $47-$ S. koltzei; $48-$ S. schevyrewi; $49-$ S. transcaspicus; 50-51-S. kirschii; 52-54-S. zaitzevi; 55-S. jaroschewskii; 41-45, 4852, 54-55 - males; 46-47, 53 - females; 43-44, 47, 51, 54 - lateral view; 41-42, 45-46, 50, 52-53, 55 — abdomen; 48-49 — heads.

Рис. 41-55. Габитус и детали короедов рода Scolytus: 41 - S. kononovi; 42-43 - S. semenovi; $44-$ S. pubescens; 45-47 — S. koltzei; $48-$ S. schevyrewi; $49-$ S. transcaspicus; 50-51 - S. kirschii; 52-54-S. zaitzevi; 55 - S. jaroschewskii; 41-45, 48-52, 54-55 - самцы; 46-47, 53 - самки; 43-44, 47, 51, 54 - сбоку; 41-42, 45-46, 50, 52-53, 55 - брюшко; 48-49 — голова. 
with pale, sparse and short, indistinct hair-like setae .... S. semenovi (female)

- Punctures on elytral striae only slightly impressed, elongate, elliptic; elytral apices with erect pointed hair-like setae; $2.0-2.3 \mathrm{~mm}$

S. kononovi (female)

18. Size of ventrite 2 denticle strongly variable, but abdominal setae always shorter than denticle and never reach its apex; lateral and lower areas of frons always with long setae....

- Setae on ventrite 2 long, extending to or longer than denticle apex

19. Ventrite 2 with short keel-like median denticle (sometimes, denticle is longer than width of ventrite 1) (Figs 37, 39); frons with long hair-like setae in lower part, apices of setae directed medially; $1.6-3.2 \mathrm{~mm}$.......... S. ensifer (female)

- Ventrite 2 with long median process as in male (Fig. 40), its apex upturned; $1.6-3.2 \mathrm{~mm}$

S. varshalovitchi (female)

20. Elytral interstriae 9 convex, with acute denticles; ventrite 2 with small keel-like denticle, its apex acute; ventrites $2-$ 4 with dense long hair-like setae, curved towards the centre of ventrites, setae on ventrite 2 of the same length as median denticle; $3.3-5.3 \mathrm{~mm}$.... S. claviger (female)

- Elytral interval 9 flat, without denticles; ventrite 2 with tiny, keel-like, strongly laterally compressed denticle, its apex acute; hair-like setae on ventrite 2 long and abundant, their length two times greater than median denticle; $2.9-4.0 \mathrm{~mm}$ S. pubescens (female)

21. Abdomen with appressed hair-like setae, on the base of ventrite 2 only, long erect setae form a single row, at the base of denticle long setae are grouped more densely and so especially prominent. In males, denticle of ventrite 2 with narrow base, strongly widening towards apex, with a groove at the top; in females denticle narrow, without apical widening....

22

- Abdomen with erect hair-like setae on all ventrites, short appressed setae present inbetween long ones. Ventrite 2 tubercle short, oval, not longer than wide, with the apex oriented slightly downwards, rounded, not split by groove at apex in both sexes (Figs 50-51)....

22. Frons with very dense, longitudinal deep wrinkles, puncturation not visible (Fig. 48); frons in males flat with long, dense hair-like setae in lateral areas, in females frons convex, with very sparse, thin, short setae, nearly glabrous; elytra with dark transverse band running from the middle of the disc towards apical edge; male genitalia with long narrow apophyses, penis tube is narrow and long (11.6-12.3 times longer than wide), 1.48 times longer than apophyses (Fig. 2), penis apex evenly rounded (Fig. 3); $2.3-4.0 \mathrm{~mm}$

S. schevyrewi (male and female) (Figs 2-3, 48)

- Frons with sparse, longitudinal shallow wrinkles, intervals between wrinkles with small punctures (Fig. 49); frons in males weakly impressed, with long, dense hairlike setae in lateral areas, in females frons convex, with very sparse, thin, short setae; elytra without dark transverse band, base of the disc just slightly paler than the rest of elytra; male genitalia with short wide apophyses, median lobe is wider (8.4-8.6 times longer than wide), 2.0 times longer than apophyses (Fig. 4); penis apex triangularly acute (Fig. 5); 3.5-4.2 mm

S. transcaspicus (male and female)

23 . Frons in males convex, completely covered with short pale more sparsely set hair-like setae, in females frons glabrous with sparse hairs present over clypeus. Body uniformly brown or dark-brown, not strongly shining, semi-matt; 2.1-3.0 mm (Figs 50-51)

S. kirschii kirschii (male and female)

- Frons in males weakly convex, almost flat; frontal pubescence in males and females more strongly developed, frons with longer yellow hair-like setae. Body brown or dark brown, usually with dark transverse band behind the middle of reddish brown elytra. $2.0-3.5 \mathrm{~mm}$ S. kirschii fasciatus (male and female)

24. Median denticle present only on ventrite 2 (Figs 52-55)

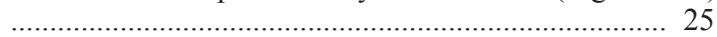

- Median denticles present on keel-like raised sutures between ventrites 2,3 and 4 ..................................... 27

25. Denticle on ventrite 2 situated in the middle of ventrite in males and near posterior margin in females; ventrite 2 nearby denticle covered with dense long erect hair-like setae; ventrite 5 with oval median transverse depression, lateral areas with raised callus-like elevations covered with long dense setae; in addition to long hairs at second ventrite all ventrites with short appressed setae; small species; $1.7-2.5 \mathrm{~mm}$....... S. zaitsevi (male and female)

- Ventrite 2 in the middle of posterior margin with short, acute denticle both in males and females (Fig. 55); ventrite 5 without median depression and raised lateral areas; all ventrites with short appressed setae; elytral puncturation uniform, punctures on striae and interstriae of the same size; large species; 2.0-5.0 $\mathrm{mm}$...................... 26

26. Male frons flat with faintly impressed central area, covered with abundant very long hair-like setae, but fine median keel from epistoma to upper level of eyes without setae (Fig. 60); female frons convex with median keel poorly raised from epistoma to the lower level of eyes, surface covered with short hairs; pronotal disc with small elliptical punctures, larger species (Figs 56-59); 3.5-5.0 mm ....... ......... S. jaroschewskii jaroschewskii (male and female)

- Male frons usually faintly convex, less often flat, surface covered with sparse moderately long, straight, hair-like setae (Fig. 63); female frons convex with short hairs; frons of males and females without median keel; pronotal disc with large and deep elliptical punctures, smaller species (Figs 61-62); 2.0-4.0 mm ....... S. jaroschewskii kostini 27. Elytra black or brownish-black, tibia and tarsi reddishbrown; frons convex, lateral areas of epistoma covered with short pale hair-like setae (more abundant in males); ventrites 2-4 with very small, barely distinct denticles (sometimes denticles may be absent), ventrites with very short sparse pale hair-like setae; $3.3-4.7 \mathrm{~mm}$....

S. chikisanii (male and female)

- Elytra reddish-brown; frons slightly convex, faintly shining, covered with sparse short yellowish-brown setae, median area with very few setae; ventrites $2-4$ with distinct median denticles; 3.4-5.4 mm

S. triarmatus (female)

28. Thickened sutures on posterior margins of ventrites 3-4 with large or small median denticles .......................... 29

- Sutures on posterior margins of ventrites 3-4 without median denticles, in some species sutures between ventrites keel-like elevated, but lack distinct denticles .... 44

29. Posterior margin of ventrites 3 or 4 with large median

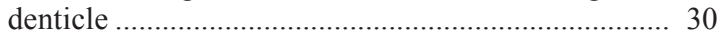

- Median denticles on posterior margins of ventrites 3-4 small, with acute apices (sometimes, denticles are indistinct, can be observed only under high magnification) .

30. Posterior margin of ventrite 3 with long flat horizontal (parallel to longitudinal body axis) process (Figs 64-65); 3.0-5.1 mm .................................. S. jacobsoni (male) 
- Denticles of ventrites 3-4 not directed parallel to longitudinal body axis, usually directed vertically downwards .

31

31. Frons with elevated median keel; posterior margin of ventrite 3 with vertical large denticle, its apex distinctly thickened (sometimes, denticle of ventrite 3 small, without apical thickening or absent); median part of posterior margin of ventrite 4 with elevated thickening bearing shallow notch in the middle (Figs 66-67); body surface shiny, dark brown, almost black, elytra paler (Fig. 17), in some specimens reddish-brown; punctures on elytral striae much larger than on interstriae; frons flat with strong longitudinal wrinkles and long yellow hair-like setae; 4.0-6.6 $\mathrm{mm}$...... S. ratzeburgii (male)

- Frons without median keel; denticle of ventrite 3 substantially smaller or absent; posterior margin of ventrite 4 elevated, with median denticle (Figs 68-69)

32

32. Frons flat, slightly depressed medially; posterior margins of ventrites 3-4 keeled, ventrite 3 with very small median denticle, ventrite 4 with flat vertical protrusion occupying about $1 / 3$ of the suture length (Figs 68-69); pronotal and elytral surfaces weakly shiny; small species, body $2.2-2.3$ times longer than wide (Fig. 18); 1.5-2.5 mm

S. pygmaeus (male)

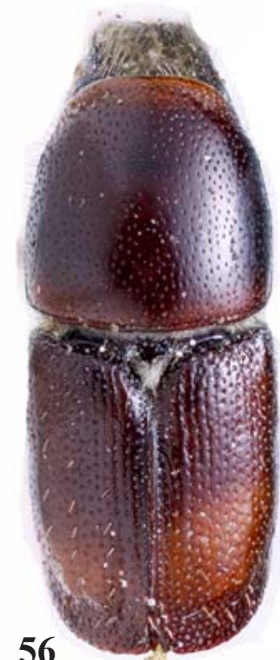

56
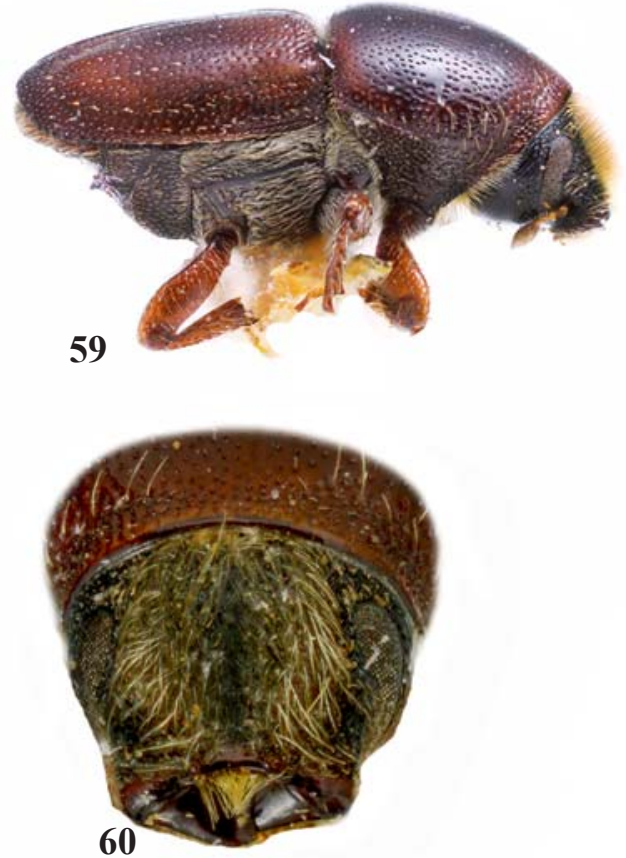

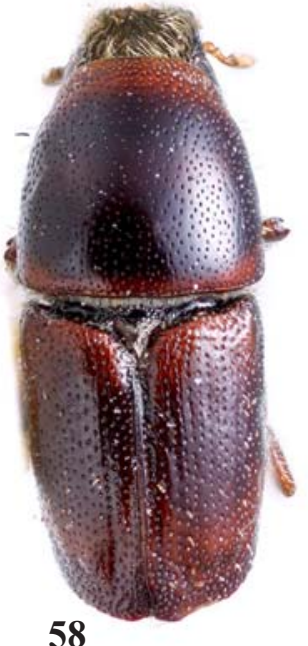

58

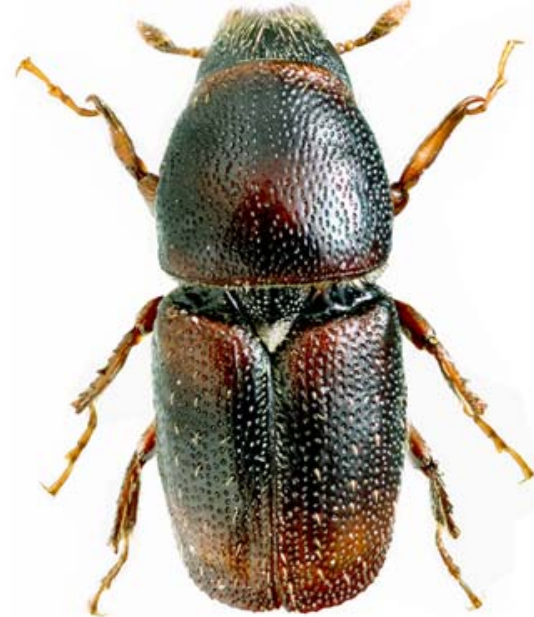

61

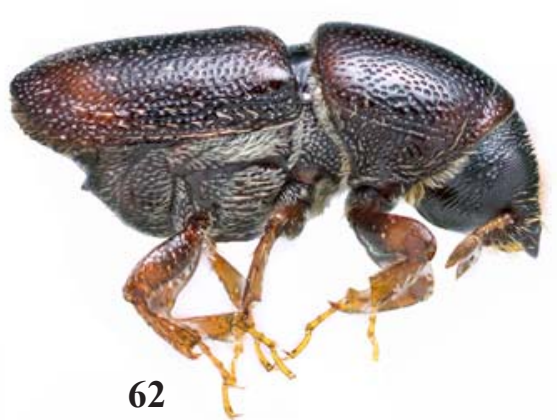

63

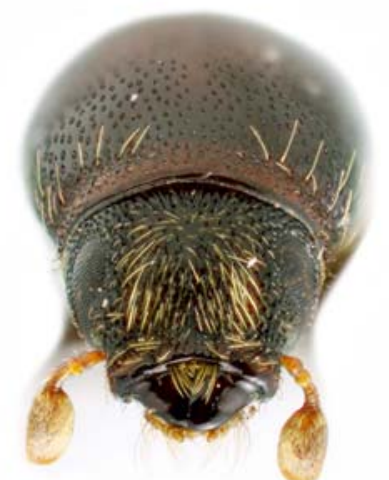

Figs 56-63. Habitus and details of males Scolytus jaroschewskii jaroschewskii and S. jaroschewskii kostini: 56 - subsp. jaroschewskii from Daghestan; 57 - subsp. jaroschewskii from Tajikistan; 58-60 - subsp. jaroschewskii from Turkmenistan; 61-63 - jaroschewskii kostini; 56-58, 61 - habitus, dorsal view; 59, 62 - habitus, lateral view; 60, 63 - head.

Рис. 56-63. Габитус и детали строения самцов Scolytus jaroschewskii jaroschewskii и S. jaroschewskii kostini: 56 — subsp. jaroschewskii из Дагестана; 57 - subsp. jaroschewskii из Таджикистана; 58-60 - subsp. jaroschewskii из Туркменистана; 61-63 jaroschewskii kostini; 56-58, 61 — сверху; 59, 62 - сбоку; 60, 63 — голова. 
- Frons flat, not depressed medially; posterior margins of ventrite 2 keeled, with median triangular projection, looking like a small tubercle in some males; posterior margin of ventrite 4 keeled, with trapezoid median denticle (occasionally, it has central notch) occupying about $1 / 5$ of the suture length (Fig. 70); pronotal and elytral surfaces shiny; larger species, body 2.5-2.6 times longer than wide; $3.2-4.5 \mathrm{~mm}$ S. laevis (male)

33. Setae on ventrite 5 apex arranged in dense bunches or brushes (Figs 72, 74, 78, 80-81)

- Setae on ventrite 5 apex not arranged in bunches or brushes, ventrite 5 with longitudinal median depression, its lateral sides weakly elevated as rounded swellings (Figs 73, 75, 79)

34. Setae on ventrite 5 apex arranged in three separate dense bunches with pointed apices (Figs 72, 74); median denticles of ventrites 3-4 very small, barely visible even under high magnification

35

- Setae on ventrite and tergite 5 apices arranged into wide brush, median denticles on ventrites 3-4 distinct..... 36

35. Posterior margin of ventrite 5 triangular; central bunch of setae wider and shorter than lateral ones, which diverge at an angle of $5-10^{\circ}$ from the central one (Fig. 72); depression in the median part of ventrite $5 \mathrm{~V}$-shaped; frons flat, covered with hair-like setae, which are longer in upper part; 3.6-6.5 mm .............................. S. esuriens (male)

- Posterior margin of ventrite 5 straight; bunches of setae are arranged in line, central and lateral bunches of approximately the same sizes and with the same directions (Fig. $74)$; depression in the median part of ventrite 5 circular; $3.6-6.5 \mathrm{~mm}$ S. trispinosus (male)

36 . Frons flat or slightly depressed, with long longitudinal wrinkles, long and dense hair-like setae on lateral areas of frons; setose brush on posterior margins of ventrite 5 and tergite 8 continuous, without breaks (Fig. 78); the rest of ventrites covered with appressed bristle-like setae; 3.0$6.0 \mathrm{~mm}$..................... S. eichhoffi (male) (Figs 19, 78)

- Frons flat or slightly convex, covered with short hair-like
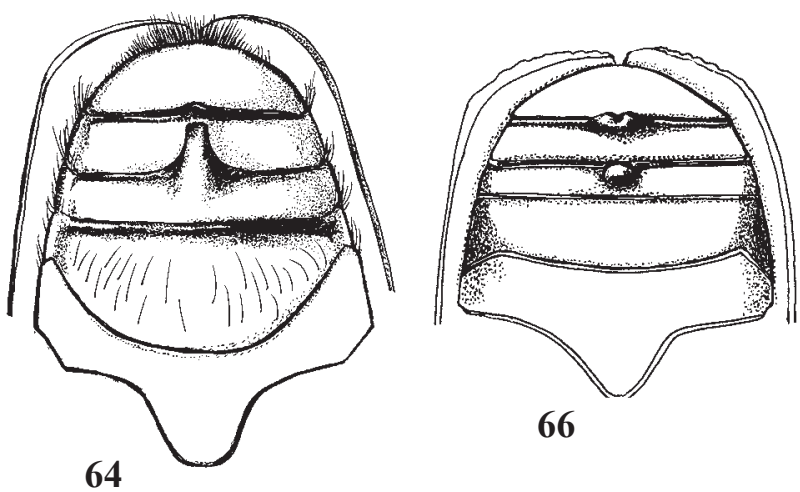

66

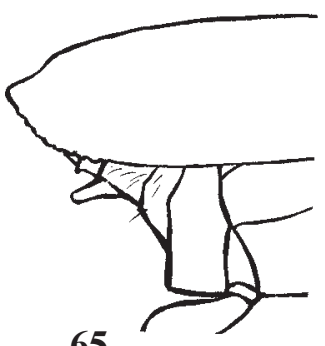

65

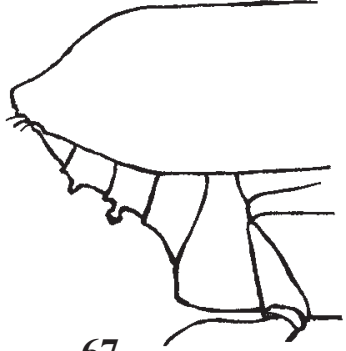

67

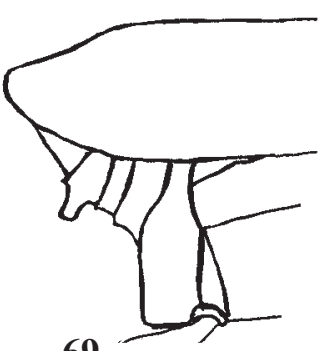

69

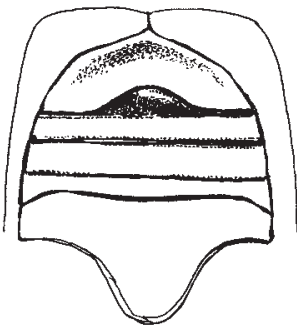

68

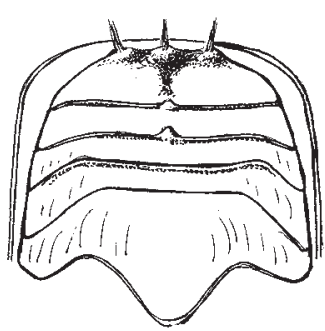

74

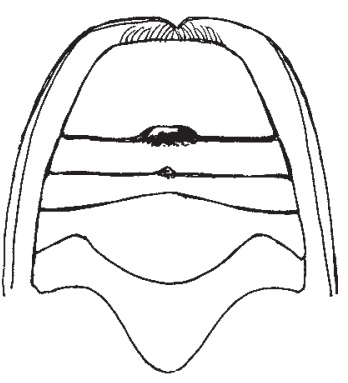

70
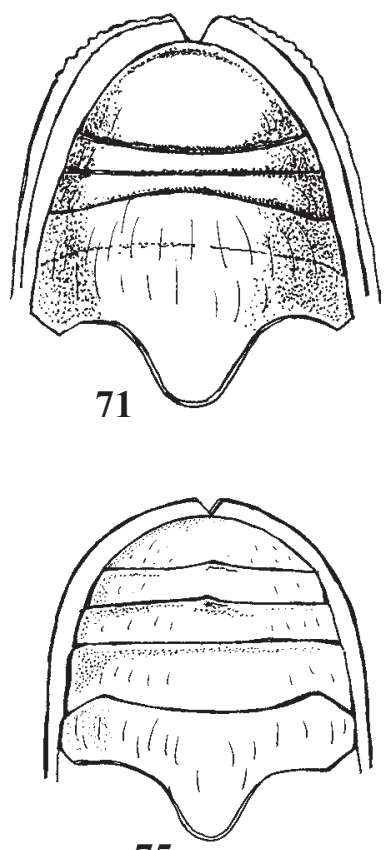

75

Figs 64-75. Habitus and details of bark beetles of the genus Scolytus: 64-65 - S. jacobsoni; 66-67 - S. ratzeburgii; 68-69 S. pygmaeus; $70-$ S. laevis; $71-$ S. rugulosus;72-73-S. esuriens; 74-75-S. trispinosus; 64-72, 74- males; 73, 75 - females; 65, 67, 69 - lateral view; 64, 66, 68,70-75 - abdomen.

Рис. 64-75. Габитус и детали строения короедов рода Scolytus: 64-65 - S. jacobsoni; 66-67 - S. ratzeburgii; 68-69 S. pygmaeus; 70 - S. laevis; 71 - S. rugulosus; 72-73 - S. esuriens; 74-75 - S. trispinosus; 64-72, 74 - самцы; 73, 75 - самки; 65, 67, 69 - сбоку; 64, 66, 68,70-75 - брюшко. 
setae

37. Frons with very short yellowish-brown setae and longitudinal wrinkles, gular area almost glabrous, with shiny surface; setose brush of ventrite 5 continuous, with hairlike setae of similar sizes, in central and lateral areas, lateral setae of the brush of tergite 8 longer than setae in the middle; $3.4-5.4 \mathrm{~mm}$ S. triarmatus (male)

- Frons and gular area with abundant short setae, frontal surface covered with small granules and sparse very short longitudinal wrinkles

38. Entire surface of frons with dense, short erect setae; abdominal apex with continuous setose brush: ventrite 5 with continuous setose brush, hair-like setae in lateral parts of it two times longer than median setae; tergite 8 with two setose bunches laterally (Fig. 80); 3.5-6.0 mm S. scolytus (male)

- Lateral parts of frons with dense short erect setae, its median part with a patch covered only with very sparse, short setae; abdominal apex with broken setose brush looking like six closely packed, but distinct bunches; tergite 8 with two narrow long setose bunches laterally (Figs 20, 81); 3.5-6.5 mm ............ S. sulcifrons (male)

39. Denticles on posterior margins of ventrites 3-4 very small, lateral profile of abdomen convex 40

- Denticles on posterior margins of ventrites 3-4 large, distinct, lateral profile of abdomen incurved, from posterior margin of ventrite 1 to ventrite 5 apex forming an angle of about $45^{\circ}$

40. Third elytral interstriae on disk with punctures arranged in a single or double rows (Fig. 76); 3.8-6.5 mm

S. esuriens (female)

- Third elytral interstriae on disk with punctures arranged in three rows (Fig. 77); 4.0-6.5 mm (Fig. 75) ......

\section{S. trispinosus (female)}

41. Frons with longitudinal wrinkles

............................ 42

- Frontal surface granulate-tuberculate ........................ 43

42. Frons flat, covered with dense hair-like setae of medium length; elytra reddish-brown; posterior margins of ventrites 3-4 with well-defined median denticles (Fig. 79); 3.0-6.0 mm ................................ S. eichhoffi (female)

- Frons convex, lateral sides of epistoma with short pale hairlike setae (more abundant in males); elytra black or darkbrown; 3.3-4.7 $\mathrm{mm}$....... S. chikisanii (male and female)
43. Frons evenly covered with short yellowish-brown hairlike setae; $3.0-6.0 \mathrm{~mm}$ S. scolytus (female)

- Frontal setae irregularly distributed, lateral areas have dense cover of short yellowish-brown setae, median parts lack setae, granular surface is distinct in this area; 3.3-6.2 $\mathrm{mm}$. S. sulcifrons (female)

44. Ventrite 5 with median depression and rounded elevated lateral swellings or protrusions densely covered with long hair-like setae..... .. 45

- Ventrite 5 without median depression and lateral swellings or protrusions, setae on ventrite 5 not arranged into brushes or bunches, their lengths do not differ from lengths of setae on ventrites $2-4$

48

45. Frons convex, with granulate surface, lacks longitudinal wrinkles; posterior margin of ventrite 2 thickened; ventrite 5 short, with small median depression and weakly raised callosities covered with long pale setae barely extending beyond posterior edges of elytra; $2.6-4.0 \mathrm{~mm}$

S. morawitzi (male)

- Frons flat or weakly convex, with longitudinal wrinkles

6. Ventrite 5 with median depression, its lateral areas elevated as large protrusions with flat tops; these protrusions covered with long bristle-like setae arranged into wide bunches, extending well beyond elytral apical margins, apices of setae bent medially, (Fig. 82); frons flat, its surface longitudinally wrinkled, long hair-like setae with medially directed apices localized on lateral parts of epistoma (Fig. 89); 4.1-4.5 mm .... S. dahuricus (male)

- Ventrite 5 with wide median depression and elevated lateral tubercles, their tops not drawn back towards elytral apices and not flattened.... 47

47. Frons weakly convex, with sparse, thin, short, hair-like setae, somewhat longer on epistoma; entire surface of ventrite 5 covered with dense pale setae not arranged into separate bunches, apices of setae extend evenly beyond elytral margin forming a regular brush (Fig. 86); 2.0-3.5 $\mathrm{mm}$.................................................... S. aratus (male)

- Lateral sides of epistoma covered with numerous setae of medium length; ventrite 5 with wide median depression, its lateral sides elevated as swellings and covered with abundant setae of moderate length (Fig. 83); 4.4-5.0 mm S. dahuricus (female)

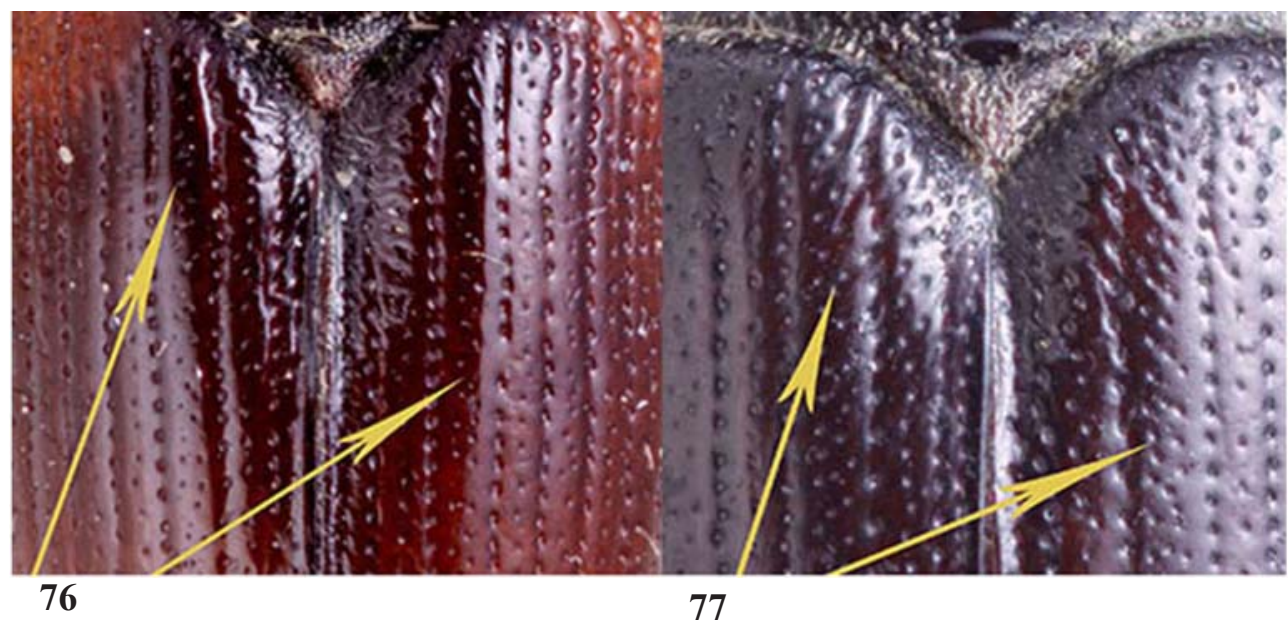

Figs 76-77. Elytral puncturation: $76-$ S. esuriens, female; $77-$ S. trispinosus, female.

Рис. 76-77. Пунктировка надкрылий: $76-$ S. esuriens, самка; $77-$ S. trispinosus, самка. 
48. Frons convex, with granulate surface, lacking longitudinal wrinkles; abdomen with sparse, erect, pale, hair-like setae, posterior margin of ventrite 5 with abundant pale setae; $2.6-4.0 \mathrm{~mm}$. S. morawitzi (female)

- Frons with longitudinal wrinkles ......................... 49

49. Elytral disk with straight, distinct, punctate striae, strial punctures much larger than punctures on interstriae ... 50

- Punctures on striae and interstriae on elytral disk almost of the same sizes and shapes, in some species punctures on striae and interstriae are confused

50. Vertex with narrow longitudinal depression ............

— Vertex without longitudinal depression ....................... 54

51. Frons with medial longitudinal keel running from epistoma to vertex, with narrow longitudinal wrinkles and sparsely granulate; elytral disk with narrow striae and wide interstriae; posterior margins of ventrites not elevated, surface of ventrite 5 flat, with evenly distributed large punctures; 4.0-6.8 $\mathrm{mm}$............ S. ratzeburgii (females)

- Frons without medial longitudinal keel...................... 52

52. Vertex with deep narrow longitudinal depression forming at the frons a flat area or shallow depression at the level of upper margin of eyes; strial punctures on elytral disc distinctly deepened, interstriae flat; posterior margin of ventrite 5 with shallow transverse depression; 3.0-5.1 $\mathrm{mm}$....... S. jacobsoni (female)

- Vertex with short narrow longitudinal depression not forming a transverse depression at the level of upper margin of eyes

53

53. Frons with few minute, scattered, thin, hair-like setae, vertex depression deep and distinct; $3.2-4.5 \mathrm{~mm}$

S. laevis (female)
- Frons with numerous short, thin, erect brown setae, vertex depression very shallow, indistinct; 3.0-4.6 mm (Figs 21, 85) S. mali (female)

54. Frons convex; ventrite 5 with wide transverse depression occupying most of the ventrite surface; $1.5-2.5 \mathrm{~mm}$.... S. pygmaeus (female)

- Frons flat: $3.04 .6 \mathrm{~mm}$

55. Frons with short, pale, hair-like setae; abdominal profile from ventrite 2 to apex angled at about $45^{\circ}$; surface of ventrite 5 flat, without local depressions, all abdominal ventrites covered in dense yellow setae (Fig. 45); male genitalia of highly extended form, with pointed apex (Figs 6-7); 3.0-4.6 mm ............................. S. koltzei (male)

- Frons laterally with short, yellowish-brown, hair-like setae, longer on epistoma; posterior margin of ventrite 4 keeled, its central part with triangular protrusion, apical portion of ventrite 5 slightly impressed (Fig. 84); abdominal ventrites with very sparse, short, indistinct setae, surface nearly glabrous; $3.0-4.6 \mathrm{~mm}$..... S. mali (male)

56. Frons with median acute, triangular denticle in epistomal area, directed longitudinally, and strongly impressed laterally (Fig. 90); frons flat in epistomal area and with convex area at the level of eyes, with dense brown hairlike setae; elytra with large punctures, punctures on striae and interstriae of the same size and shape, interstriae on disk with erect pale hair-like setae; posterior margin of ventrite 2 keeled, all ventrites covered with erect pale setae; 2.2-2.5 mm (Fig. 22) ..... S. gretschkini (female)

- Frons without median acute denticle ......................... 57

57. Frons flat, epistoma above mandibles with a pair of erect pointed brushes of dense setae 58

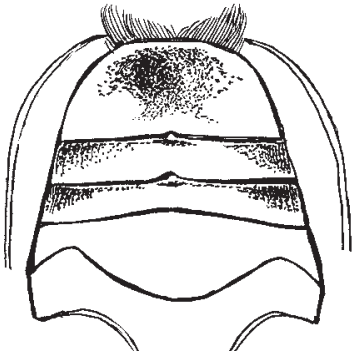

78

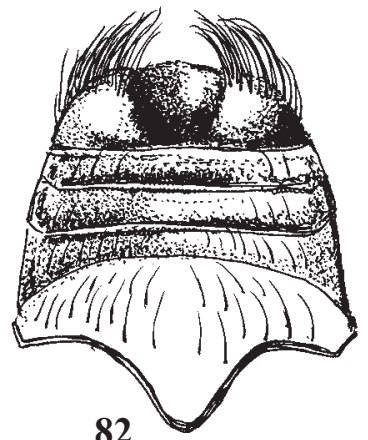

82

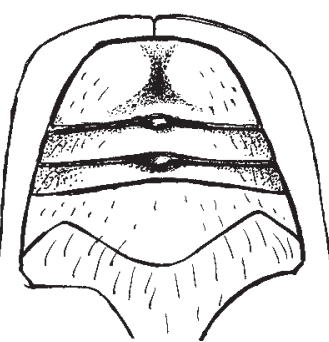

79

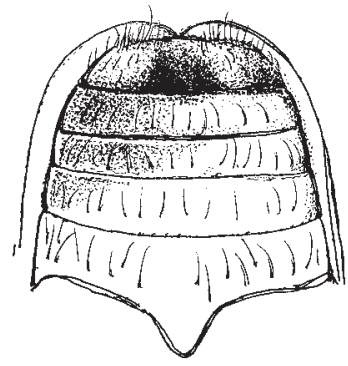

83

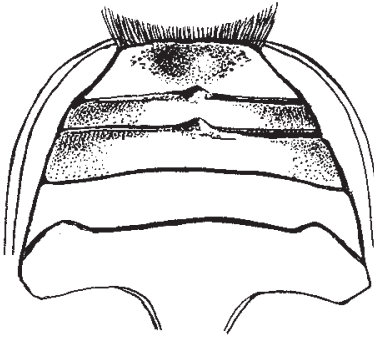

80

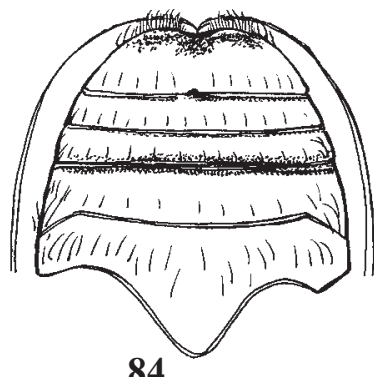

84

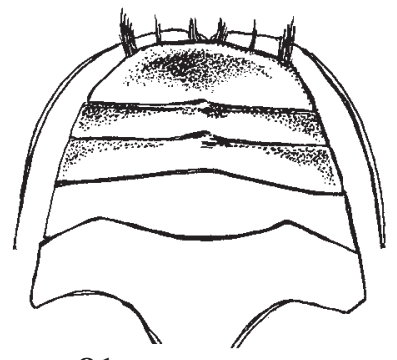

81

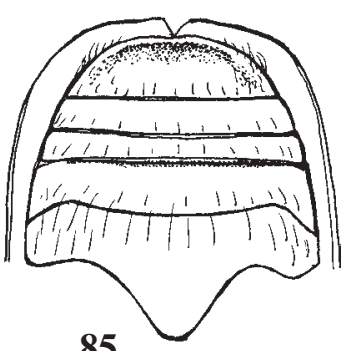

Figs 78-85. Details of bark beetles of the genus Scolytus: 78-79-S. eichhoffi; $80-S$. scolytus; $81-S$. sulcifrons; 82-83-S. dahuricus; 84-85 - S. mali; 78, 80-82, 84 - males; 79, 83, 85 - females; 78-85 - abdomen.

Рис. 78-85. Детали строения короедов рода Scolytus: 78-79-S. eichhoffi; $80-$ S. scolytus; $81-$ S. sulcifrons; 82-83 - S. dahuricus; 84-85-S. mali; 78, 80-82, 84 - самцы; 79, 83, 85 - самки; 78-85 - брюшко. 
- Frons without a pair of erect pointed brushes above mandibles 59

58. Frons with depression from epistoma to vertex, its surface glossy shining, epistoma with short median keel, brushes above mandibles with reddish-brown setae, elevated lateral sides of frons bear long setae with apices oriented medially (Fig. 23); from eye level to vertex setae become longer and their tips hang over the middle of the frons (Fig. 88); elytral striae regular, punctures on striae and interstriae do not differ in size and shape, striae not impressed on elytral disc; ventrite 5 with strongly elevated posterior margin; hair-like setae on ventrites $1-2$ very long, two times longer than setae on other ventrites; male genitalia with an extended median lobe and short apophyses, apical third with sclerotized pointed tubercles (Figs 13-14); 3.3-4.7 mm ........... S. tadzhikistanicus (male)

- Frons flat, its surface dull, brushes above mandibles with yellowish-brown setae, lateral sides of frons bear short and thin hair-like setae; ventrite 5 with weakly elevated posterior margin; setae on ventrites short and sparse; 2.4 $4.3 \mathrm{~mm}$. S. intricatus (male)

59. Abdominal profile convex, smoothly arched at the juncture of ventrites 1 and 2 ....

60

- Abdominal profile concave, angled at $60-70^{\circ}$ at the juncture of ventrites 1 and 2

60. Suture between ventrites 1 and 2 poorly visible (Fig. 71 91); pronotal puncturation rugose, punctures elliptical, often longitudinal wrinkles present on surface, especially in antero-lateral areas, where punctures often fuse; frons in males with short erect hair-like setae (Fig. 92), in females with sparse short pale setae (Fig. 93); male genitalia with short straight median lobe (fig 1); 1.4-3.3 $\mathrm{mm}$ S. rugulosus (male and female)

- Suture between ventrites 1 and 2 clearly visible ....... 61

61 . Ventrite 5 triangular, with pointed apex and elevated lateral borders (Fig. 87); puncturation of pronotum and elytra variable, surface may be shiny or dull, punctures may be small to large and rugose; male genitalia with sickle-shaped median lobe (Fig. 8); $1.5-3.5 \mathrm{~mm}$ S. japonicus (male and female)
- Ventrite 5 with rounded apex and without elevated lateral

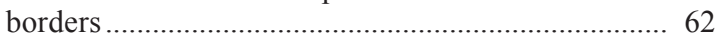

62. Frons with longitudinal keel from epistoma to vertex (Fig. 97), in males with pale, hair-like setae with apices directed medially (Fig. 96), in females with sparse, short, thin setae; sutures between ventrites $2-4$ thickened and elevated; elytra reddish-brown with dark band in the middle of the disc; $2.0-3.5 \mathrm{~mm}$... S. amygdali (male and female)

- Frons without longitudinal keel, elytra without dark band on disc ....

63

63. Frons convex with short, sparse, pale setae on lateral parts of epistoma; pronotum with few scattered appressed setae in antero-lateral areas; elytra reddish-brown with sparse, pale setae on declivity; posterior end of ventrite 5 with round depression occupying half of posterior part of ventrite; $2.0-3.5 \mathrm{~mm}$......................... S. aratus (female)

- Frons flat with long pale hair-like setae; pronotum covered with numerous long erect setae; elytral interstriae with erect bristle-like setae; ventrite 5 without depression; $2.2-2.5 \mathrm{~mm}$

S. gretschkini (male)

64. Frons flat, male .......................................................... 65

- Frons convex, female .................................................. 66

65. Frons with median depression, lateral areas weakly raised and covered with dense yellow setae (Fig. 19); elytra with round deep punctures arranged into regular striae on disc; outer edge of elytral apex dentate; sutures between ventrites 2-5 not raised, with abundant erect brown setae; $3.2-4.4 \mathrm{~mm}$ S. koenigi (male)

- Frons flat, lateral areas not raised, covered with short erect pale setae; outer edge of elytral apex not dentate; sutures between ventrites $2-5$ keeled (especially between ventrites 2 and 3), with sparse appressed pale setae; $2.0-4.2$ $\mathrm{mm}$. S. carpini (male)

66. Posterior part of ventrite 5 with local elliptical depression; frons densely covered with setae of medium length, their apices directed medially; ventrites covered with very sparse, short, indistinct setae; $3.6-4.7 \mathrm{~mm}$ S. tadzhikistanicus (female)

— Ventrite 5 without depression .................................... 67

67. Entire surface of frons covered with dense, short, erect,
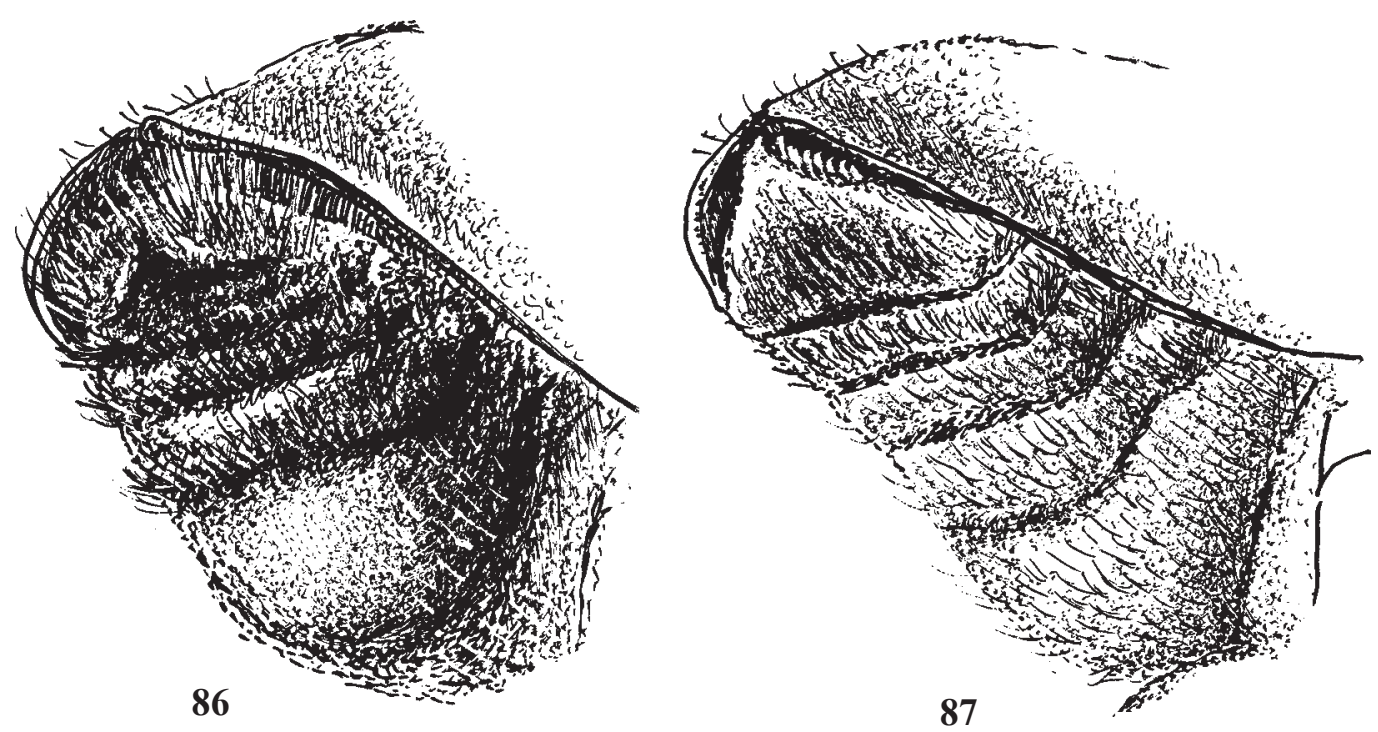

Figs 86-87. Details of bark beetles of the genus Scolytus: 86 - abdomen of S. aratus, male; 87 - abdomen of S. japonicus, male. Рис. 86-87. Детали строения короедов рода Scolytus: 86 - брюшко S. aratus, самец; 87 - брюшко S. japonicus, самец. 
brown setae; outer edge of elytral apex dentate; ventrites covered with short erect brown setae; $3.2-4.4 \mathrm{~mm}$....... S. koenigi (female)

- Frons with short sparse setae only laterally 68

68. Elytral surface dull, disc with shallow punctures on striae and interstriae, with oblique wrinkles between them; outer edge of elytral apex dentate; ventrites dull, with dense short erect pale setae; $2.4-4.3 \mathrm{~mm}$

\section{S. intricatus (female)}

- Elytral surface weakly shining, disc with shallow punctures on striae; outer edge of elytral apex not dentate; ventrites shining, with short sparse setae; $2.0-4.7 \mathrm{~mm}$. S. carpini (female)

Annotated list of species of Scolytus of Russia and neighboring countries.

\section{S. amygdali Guérin-Méneville, 1847} Figs 96-97.

= aegyptiacus Pic, 1920

= anatolicus Eggers, 1911.

= mailleri Eggers, 1912

= rufipennis Brancsik, 1874.

DISTRIBUTION. Russia: Crimea, North Caucasus (Dagestan); Caucasus (Armenia, Georgia); central and southern
Europe; Asia (Iran, Iraq, Middle East, Pakistan, Turkey); North Africa; Oriental Region.

HOSTS. Different species of Rosaceae, mainly on Prunus armeniaca, P.dulcis, P.persica, rarely on Amelanchier sp., Mespilus sp. and other hosts.

\section{S. aratus Blandford, 1894}

Fig. 86.

= aequipunctatus Niisima, 1905.

= brevipennis Kurenzov, 1941

= intermedius Kurenzov, 1941

DISTRIBUTION. Russia: Amur Prov., South Primorsk Terr., Sakhalin, Kunashir Island; Asia (China, Northeast provinces: Heilongjiang, Jilin; Japan, North Korea, South Korea).

HOSTS. Ulmus japonica, U. pumila, rarely on Carpinus sp. and Prunus sp.

\section{S. butovitschi Stark, 1936 Figs 26-29.}

= butovitschi Eggers, 1942

DISTRIBUTION. Russia: Transbaikalia, South Primorsk Terr.; Asia (China, including Heilongjiang; Mongolia). HOSTS. Ulmus japonica, U. pumila, Ulmus sp.

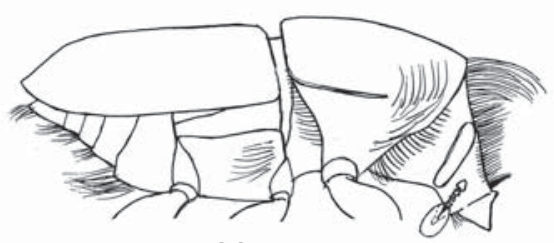

88

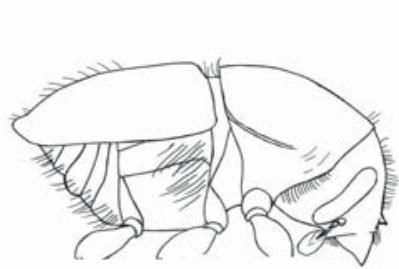

90

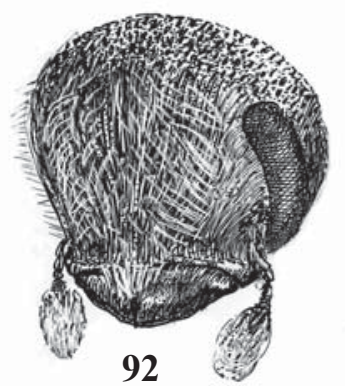

92

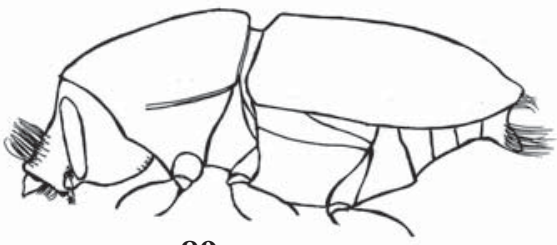

89
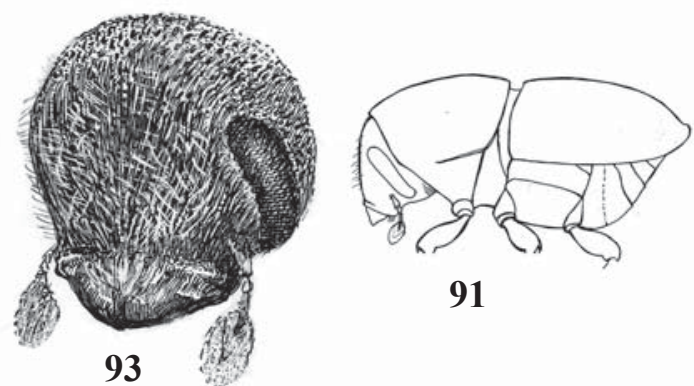

91
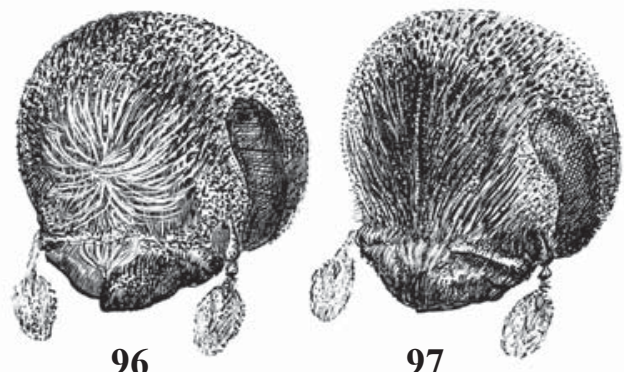

97
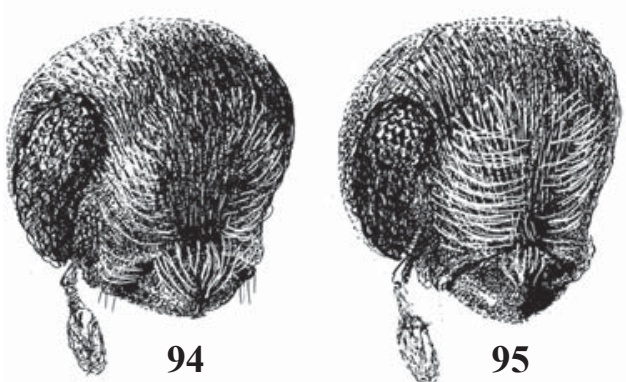

Figs 88-97. Habitus and details of bark beetles of the genus Scolytus: $88-$ S. tadzhikistanicus; $89-$ S. dahuricus; $90-$ S. gretschkini; 91-93 - S. rugulosus; 94-95 - S. japonicus; 96-97 - S. amygdali; 88-89, 92, 95-96 - males; 90-91, 93-94, 97 — females; 88-91 habitus, lateral view; $92-97$ - head.

Рис. 88-97. Габитус и детали строения короедов рода Scolytus: $88-$ S. tadzhikistanicus; $89-$ S. dahuricus; $90-$ S. gretschkini; 91-93 - S. rugulosus; 94-95 — S. japonicus; 96-97 — S. amygdali; 88-89, 92, 95-96 — самцы; 90-91, 93-94, 97 — самки; 88-91 — сбоку; 92-97 - голова. 


\section{S. carpini (Ratzeburg, 1837)}

= balcanicus Eggers, 1911 .

= peregrinus Eggers, 1908 .

DISTRIBUTION. Russia: Crimea, Kaliningrad Prov., Kursk Prov., North Caucasus; European countries of the former USSR (Estonia, Latvia, Ukraine); Caucasus; central and southern Europe; Asia (Turkey).

HOSTS. Carpinus betulus, C. caucasicus, C. orientalis, Fagus spp., Quercus spp., Corylus avellana.

\section{S. chikisanii Niisima, 1905}

= curviventralis Niisima, 1905.

= mandschuricus Schedl, 1941 .

DISTRIBUTION. Russia: South Primorsk Terr., Sakhalin, Kunashir Island; Asia (China, including Northeast Territory; Japan, North Korea).

HOSTS. Ulmus spp.

\section{S. claviger Blandford, 1894}

= platystylus Wichmann, 1915 .

DISTRIBUTION. Russia: South Primorsk Terr.; Asia (China, Japan, North Korea, South Korea).

HOSTS. Carpinus cordata.

\section{S. dahuricus Chapuis, 1869}

Figs 82-83, 89.

= agnatus Blandford, 1894

= possyeti Stark, 1938 .

DISTRIBUTION. Russia: Transbaikalia, Amur Prov., South Primorsk Terr., Sakhalin, Iturup Island, Kunashir Island; Asia (China, Northeast provinces: Heilongjiang, Jilin; Japan, North Korea).

HOSTS. Betula costata.

\section{S. ecksteini Butovitsch, 1929 Figs 33-35.}

DISTRIBUTION. Russia: North Caucasus (Dagestan, Samur Forest); Caucasus (Azerbaijan); Middle Asia (Kazakhstan, Turkmenistan); Asia (Iran).

HOSTS. Ulmus minor.

\section{S. eichhoffi Reitter, 1895}

Figs 19, 77-78.

= iranicus Eggers, 1941.

DISTRIBUTION. Caucasus (Azerbaijan); Europe (Bulgaria); Asia (Iran).

HOSTS. Ulmus minor.

\section{S. ensifer Eichhoff, 1881 Figs 16, 36-39.}

DISTRIBUTION. Russia: European part(Astrakhan, Belgorod, Kursk, Lipetsk, Saratov, Volgograd, Voronezh Provinces, to the north up to forest-steppe biotopes in Oka River valley in the southernmost Moscow Prov.) Crimea; European countries of the former USSR (Moldova, Ukraine); Caucasus (Azerbaijan); central and southern Europe; Asia (Iran, Turkey).

HOSTS. Ulmus minor, U. glabra, U. laevis, U. elliptica, rarely on Prunus sp.

\section{S. esuriens Blandford, 1894}

Figs 72-73, 76

= sachalinensis Michalski, 1964.

DISTRIBUTION. Russia: South Primorsk Terr., Sakhalin, Kunashir Island; Asia (China, including Northeast provinces: Heilongjiang, Jilin; Japan).

HOSTS. Ulmus laciniata, Ulmus sp.

\section{S. gretschkini Sokanovskiy, 1956} Figs 22, 90.

DISTRIBUTION. Middle Asia(Tajikistan:Hissar-DarvazMts). HOSTS. Prunus cerasifera, P.dulcis.

\section{S. intricatus (Ratzeburg, 1837)}

= lenkoranus Eggers, 1942.

= penicillatus Reitter, 1913 .

= picicolor Stephens, 1830 .

= simmeli Eggers, 1923 .

DISTRIBUTION. Russia: European part in oak range, Crimea, North Caucasus; European countries of the former USSR (Belarus, Estonia, Latvia, Lithuania, Moldova, Ukraine); Caucasus and Transcaucasia (Armenia, Azerbaijan, Georgia); Middle Asia (Western Kazakhstan); Europe; Asia (Iran, Turkey); North Africa.

HOSTS. Quercus robur, Q. pubescens, Quercus spp., less frequently on Carpinus sp., Fagus spp., Castanea sativa, rarely on other hosts.

\section{S. jacobsoni (Spessivtsev, 1919)}

Figs 64-65.

= montana Kurentsov, 1935.

= rimskii Kurenzov, 1941 .

DISTRIBUTION. Russia: Khabarovsk Terr., Primorsk Terr., Sakhalin; Asia (China, including Northeast provinces: Heilongjiang, Japan, North Korea).

HOSTS. Ulmus japonica, U. laciniata, U. pumila, rarely on Carpinus sp., Pyrus sp.

\section{S. japonicus Chapuis, 1875}

Figs 8, 87, 94-95.

= confusus Eggers, 1922 .

= mandli Eggers, 1922 .

= starki Kurenzov, 1941 .

= subconfusus Eggers, 1941.

= ussuriensis Kurenzov, 1941 .

DISTRIBUTION. Russia: Transbaikalia, South Primorsk Terr.; Asia (China, including Northeast provinces: Heilongjiang, Jilin, Japan, Mongolia, North Korea, South Korea).

HOSTS. Ulmus japonica, U. laciniata, U. pumila, Prunus sp., rarely on Fraxinus sp. and other hosts.

16. S. jaroschewskii jaroschewskii Schevyrew, 1893 Figs 56-60.

= granulifer Reitter, 1913 .

= rufostriatus Sokanovskiy, 1956.

= tauricus Eggers, 1914.

=unispinosus Schevyrew, 1890 .

DISTRIBUTION. Russia: North Caucasus (Stavropol Prov., Dagestan, Samur Forest); Caucasus and Transcaucasia (Armenia, Azerbaijan, Georgia); Middle Asia (Tajikistan, Turkmenistan, Uzbekistan); Asia (Afghanistan, Iran). The indication of the species for Ul'yanovsk Prov. of Russia (Mandelshtam, Isaev, 2006) should be verified.

HOSTS. Elaeagnus angustifolia, E. oxycarpa, Ulmus sp.

\section{S. jaroschewskii kostini Sokanovskiy, 1954} Figs 61-63.

DISTRIBUTION. Middle Asia (East Kazakhstan). HOSTS. Elaeagnus oxycarpa.

\section{S. kirschii kirschii Skalitzky, 1876} Figs 50-51.

= ruguloides Sokanovskiy, 1954.

DISTRIBUTION. Russia: European part of Russia (Astrakhan, Belgorod, Rostov, Volgograd, Voronezh Provinces), Crimea, North Caucasus, West Siberia; European coun- 
tries of the former USSR (Moldova, Ukraine); Caucasus; central and southern Europe; Asia (Iran, Iraq, Israel, Turkey); North Africa. Introduced into South Africa.

HOSTS. Ulmus laevis, U. pumila, rarely on Fraxinus sp., Populus sp.

S. kirschii fasciatus Reitter, 1890

= demaisoni Eggers, 1912.

DISTRIBUTION. Russia: North Caucasus; Transcaucasia (Armenia), Middle Asia (Turkmenistan, Uzbekistan); Europe (France, Italy, Spain); Asia (Iran, Turkey); North Africa.

HOSTS. Ulmus spp., Prunus armeniaca, P.persica.

18. S. koenigi Schevyrew, 1890

Figs 9-10, 25.

= aceris Knotek, 1892

= belokanicus Stark, 1941

= siculus Eggers, 1908 .

DISTRIBUTION. Russia: European part of Russia (Belgorod, Lipetsk, Saratov, Ul'yanovsk regions). North Caucasus; European countries of the former USSR (Moldavia, Ukraine); Caucasus; Middle Asia (Turkmenistan); central and southern Europe; Asia (Iran, Iraq, Turkey); North Africa.

HOSTS. Acer platanoides, Acer campestre, Acer spp.

19. S. koltzei Reitter, 1894

Figs 45-47.

= shanhaiensis Yin \& Huang, 1980.

= vexator Reitter, 1913.

= yablonianus Murayama, 1943.

DISTRIBUTION. Russia: South Primorsk Terr.; Asia (China, including Northeast provinces, North Korea).

HOSTS. Tilia sp.

\section{S. kononovi Kurenzov, 1941}

Fig. 41.

DISTRIBUTION. Russia: South Primorsk Terr. HOSTS. Malus sp.

\section{S. laevis Chapuis, 1869}

Fig. 70.

= azerbaidzhanicus Michalski, 1964.

= loevendali Eggers, 1912 .

= pomacearum Butovitsch, 1929.

DISTRIBUTION. Russia: European part (to the North up to the southern Ladoga Lake shore in Leningrad Prov. and Kirov Prov.), North Caucasus; European countries of the former USSR (Belarus, Estonia, Latvia, Moldova, Ukraine), Caucasus; Europe.

HOSTS. Ulmus spp., rarely on other hosts.

\section{S. mali (Bechstein, 1805)}

$$
\text { Figs 21, 84-85. }
$$

= bicallosus Eggers, 1933

= castaneus Ratzeburg, 1837.

= nitidulus Chapuis, 1869.

= pruni Ratzeburg, 1837.

= pyri Ratzeburg, 1837 .

= strigilatus Reitter, 1908 .

= sulcatus LeConte, 1868 .

DISTRIBUTION. Russia: European part (to the north up to St. Petersburg), North Caucasus, Western and Eastern Siberia (to the east up to Transbaikalia); European countries of the former USSR (Belarus, Estonia, Latvia, Lithuania, Moldova, Ukraine), Caucasus; Europe; Asia (Iran, Turkey); North Africa. Introduced to North America.

HOSTS. Different genera and species of Rosaceae.
23. S. morawitzi Semenov, 1902

= pini Eggers, 1942 .

DISTRIBUTION. Russia: North of European part, Western and Eastern Siberia, Tuva, Transbaikalia, Chita Prov., Yakutia (Republic of Sakha), Amur Prov., Khabarovsk Terr., Primorsk Terr., Sakhalin; Asia (China, including Northeast provinces: Heilongjiang, Mongolia, North Korea).

HOSTS. Larix spp., occasionally on Pinus koraiensis.

\section{S. multistriatus (Marsham, 1802)}

Figs 15, 31-32.

= abhorrens Wichmann, 1913.

= flavicornis Chevrolat, 1835 .

= javanus Chapuis, 1869 .

= kozikowskii Michalski, 1964.

= nodifer Reitter, 1913

= papuanus Schedl, 1936.

= therondi $\mathrm{A}$. Hoffmann, 1939.

= triornatus Eichhoff, 1881 .

$=$ ulmi L. Redtenbacher, 1847 .

DISTRIBUTION. Russia: European part of Russia (northern border at northernmost part of Leningrad Prov., northernmost part Ivanovo Prov., Perm Prov.), Crimea, North Caucasus; European countries of the former USSR (Belarus, Estonia, Latvia, Lithuania, Moldova, Ukraine); Middle Asia (Uzbekistan); Europe (northern border in southern Sweden). Asia (Iran, Turkey); North Africa. Introduced to North America, South America and New Guinea.

HOSTS. Ulmus spp.

25. S. nunbergi Michalski, 1964

DISTRIBUTION. Russia: South Primorsk Terr.

HOSTS. Unknown.

26. S. orientalis (Eggers, 1910)

Fig. 30

= affinis Eggers, 1914 .

DISTRIBUTION. Russia: Crimea, North Caucasus (Krasnodar Terr., Dagestan); Caucasus and Transcaucasia (Armenia, Azerbaijan, Georgia); Middle Asia: (Turkmenistan); Europe (Bulgaria, Romania); Asia (Iran, Turkey).

HOSTS. Ulmus spp., Zelkova carpinifolia.

27. S. pubescens Stark, 1936

Fig. 44.

= pubescens Eggers, 1942.

DISTRIBUTION. Russia: South Primorsk Terr.; Asia (North Korea, South Korea).

HOSTS. Ulmus sp.

28. S. pygmaeus (Fabricius, 1787) Figs 18, 68-69.

= armatus Comolli, 1837.

= noxius Ratzeburg, 1837.

DISTRIBUTION. Russia: European part (to the north up to St. Petersburg), Crimea, North Caucasus; European countries of the former USSR (Lithuania, Moldova, Ukraine), Caucasus (Armenia, Azerbaijan, Georgia), Middle Asia (Kazakhstan: Almaty region); Europe; Asia (Iran, Turkey).

HOSTS. Ulmus spp., rarely on other hosts.

\section{S. ratzeburgii E.W. Janson, 1856}

Figs 17, 66-67.

= amurensis Eggers, 1908

= bituberculatus Puzyr, 1951

= lineatus Kurenzov, 1941.

= sahlbergi Eggers, 1912 .

= sibiricus Eggers, 1922 . 
DISTRIBUTION. Russia: European part, North Caucasus, Western and Eastern Siberia, Transbaikalia, Amur Prov., Khabarovsk Terr., Primorsk Terr., Sakhalin, Kamchatka); European countries of the former USSR (Belarus, Estonia, Latvia, Lithuania, Moldova, Ukraine), Caucasus; Middle Asia (Kazakhstan); Europe; Asia (China, Northeast provinces: Heilongjiang, Jilin; Iran, Japan, Mongolia, North Korea, South Korea, Turkey)

HOSTS. Betula spp.

30. S. rugulosus (P.W. J. Müller, 1818)

Figs 1, 24, 71, 91-93.

$=$ assimilis Boheman, 1858 .

= baluchistani Schedl, 1958 .

= caucasicus Butovitsch, 1929

= fauveli Reitter, 1895 .

= haemorrhous Schmidberger, 1837

= intermedius Sokanovskiy, 1960

= manglissiensis Lezhava, 1940

= mediterraneus Eggers, 1922.

= punctatus Ratzeburg, 1837.

= samarkandicus Butovitsch, 1929.

= sanctaluciae A. Hoffmann, 1935.

= similis Butovitsch, 1929.

= taxicola Lezhava, 1943 .

DISTRIBUTION. Russia: European part (to the north up to Arkhangelsk), North Caucasus, Western and Eastern Siberia, Transbaikalia; European countries of the former USSR (Belarus, Estonia, Latvia, Lithuania, Moldova, Ukraine), Caucasus (Armenia, Azerbaijan, Georgia), Middle Asia (Kazakhstan, Kyrgyzstan, Tajikistan, Turkmenistan, Uzbekistan); Europe; Asia (Afghanistan, China: Xinjiang and Gansu, Cyprus, Iran, Iraq, Israel, Lebanon, Mongolia, Pakistan, Saudi Arabia, Syria, Turkey); North Africa, Oriental Region. Introduced to North and South America.

HOSTS. Different genera and species of Rosaceae, recorded once on Taxus baccata.

\section{S. schevyrewi Semenov, 1902}

Figs 2-3, 48.

= emarginatus Wichmann, 1915.

= frankei Wichmann, 1915 .

= seulensis Murayama, 1930.

= sinensis Eggers, 1910 .

DISTRIBUTION. Russia: Primorsk Terr., Novosibirsk Prov., Irkutsk Prov., Altay, Transbaikalia; Middle Asia (Kazakhstan, Kyrgyzstan, Uzbekistan); Asia (China, including Northeast provinces: Heilongjiang, Jilin and also in Xinjiang; Mongolia, North Korea, South Korea). Introduced to North America.

HOSTS. Ulmus spp., Padus sp., also on some other Rosaceae and Caragana spp.

\section{S. scolytus (Fabricius, 1775)} Fig. 80.

= bostrichus Tigny, 1801 .

= californicus LeConte, 1868 .

$=$ destructor Olivier, 1795.

= fuchsi Reitter, 1913 .

= geoffroi Goeze, 1777 .

$=$ niger Geoffroy, 1785 .

= punctatus $\mathrm{O}$. F. Müller, 1776 .

= scolythus Sulzer, 1776 .

= variabilis Sokanovskiy, 1958 .

DISTRIBUTION. Russia: European part (northern border at northernmost part of Leningrad Prov. and at Kirov Prov.), North Caucasus, Southern Ural, Western and Eastern Siberia (to the east up to Irkutsk); European countries of the former USSR (Belarus, Estonia, Latvia, Lithuania, Ukraine); Caucasus; Middle Asia (Kazakhstan, Uzbekistan); Europe (in range of Ulmus, besides Finland); Asia (Iran, Turkey).

HOSTS. Ulmus sp., occasionally on other hosts.

\section{S. semenovi (Spessivtsev, 1919)} Figs 42-43.

DISTRIBUTION. Russia: South Primorsk Terr., Transbaikalia; Asia (China, including Northeast provinces: Heilongjiang, Jilin), Mongolia, North Korea, South Korea.

HOSTS. Ulmus spp.

\section{S. sulcifrons Rey, 1892}

$$
\text { Figs 20, } 81 .
$$

= leonii Eggers, 1908 .

DISTRIBUTION. Russia: central and southern regions of the European part, Crimea, North Caucasus; European countries of the former USSR (Ukraine); Caucasus; Middle Asia: (Western Kazakhstan); southern Europe, Asia (Iran).

HOSTS. Ulmus spp.

35. S. tadzhikistanicus Stark, 1941 Figs 13-14, 23, 88. Mts)

DISTRIBUTION. Middle Asia (Tajikistan: Hissar-Darvaz

HOSTS. Acer turkestanicum, A. pubescens, Malus sieversii.

\section{S. transcaspicus Eggers, 1942} Figs 4-5, 49.

DISTRIBUTION. Russia: European part (Astrakhan, Volgograd Provinces), North Caucasus; Middle Asia (Western Kazakhstan, Tajikistan, Turkmenistan); Asia (Iran).

HOSTS. Ulmus minor, U. pumila.

\section{S. triarmatus (Eggers, 1912)}

DISTRIBUTION. Russia: Kaliningrad prov.; European countries of the former USSR (Estonia); Europe (Austria, Denmark, France, Italy, Norway, Slovakia, Sweden, Switzerland, "Yugoslavia"), Asia (Iran).

HOSTS. Ulmus sp.

\section{S. trispinosus Strohmeyer, 1908} Figs 74-75, 77.

= grandis Kurentsov, 1941.

= ventrosus Schevyrew, 1890 .

DISTRIBUTION. Russia: South Primorsk Terr., Sakhalin, Kunashir Island, East Siberia; Asia (China: Northeast provinces; Japan, North Korea).

HOSTS. Ulmus laciniata, U. japonica, U. pumila.

\section{S. varshalovitchi Michalski, 1973} Fig. 40

DISTRIBUTION. Caucasus (Azerbaijan); Asia (Iran). HOSTS. Carpinus caucasicus, Zelkova sp.

40. S. zaitzevi Butovitsch, 1929

Figs 11-12, 52-54.

DISTRIBUTION. Russia: Rostov Prov., Crimea, North Caucasus; countries of the former USSR (Southern Ukraine); Caucasus (Georgia).

HOSTS. Ulmus minor, Ulmus sp.

ACKNOWLEDGEMENTS. We express our most sincere gratitude to Dr. Boris A. Korotyaev (Zoological Institute, St. Petersburg, Russia), Alexey Gusakov (Zoological 
Museum of Moscow University, Russia), Dr. Harald Schillhammer (Natural History Museum, Vienna, Austria) for providing access to the collections. The authors thanks K.V. Makarov, M.V. Chemeris, A.V. Kompantsev, S.A. Kurbatov, Yu.N. Sundukov, I.V. Melnik, A.Yu. Muhanov, A.V. Napolov, V.V. Perov, A.V. Shamaev, E.A. Yakushkin and A.A. Zaytsev, for the provided entomological material.Special gratitude is addressed to A.K. Tishechkin for proofreading the manuscript. The research was supported by a grant from the Russian Fund for Basic Research (No.17-04-00360a). Michail Mandelshtam's contribution was also supported by the Center for collective use of scientific equipment "Renewable resources, energy sources, new materials and biotechnology (SPbFTU)" (Project 2019-0420).

\section{References}

Butovitsch V., von. 1929. Studien über die Morphologie und Systematik der paläarktischen Splintkäfer // Stettiner Entomologische Zeitung. Bd.90. $72 \mathrm{~S}$.

Knížek M. 2011. Scolytinae // I. Löbl, A. Smetana (eds.). Catalogue of Palaearctic Coleoptera. Vol.7. Stenstrup: Apollo Books. P.86-87, 204-251

Krivolutskaya G.O. 1958. [Bark beetles of Sakhalin Island]. Moskva-Leningrad: Akademia nauk SSSR. 196 pp. [In Russian]

Krivolutskaya G.O. 1996. [Family Scolytidae - bark-beetles] // Lehr P.A. (ed.). Opredelitel' nasekomykh Dal'nego Vostoka Rossii [Keys to the insects of the Russian Far East], Vol.3. Pt.3. Vladivostok: Dal'nauka. P.312-373 [in Russian].

Kurentsov A.I. 1941. Koroedy Dal'nego Vostoka SSSR [Barkbeetles of the USSR Far East] Moscow-Leningrad: Izdatel'stvo Akademii Nauk SSSR. 234 pp. [In Russian, with English descriptions of new species]

Mandelshtam M.Yu., Isaev A.Yu. 2006. [The bark-beetles (Curculionoidea: Scolytidae) of the Uluanovsk province] // Samarskaya Luka: Bulletin. No.17. P.90-100 [in Russian].

Mandelshtam M.Yu., Petrov A.V. 2016. Notes on Oriental Scolytus (Coleoptera: Curculionidae: Scolytinae) // Zoosystematica Rossica. Vol.25. No.2. P.295-298.

Michalski J. 1973. Revision of the Palearctic species of the genus Scolytus Geoffroy (Coleoptera, Scolytidae) // Polska Akademia Nauk. Zaklad Zoologii Svstematycznej i Doswiadczalnej. 214 pp. [In English, Polish and Russian]
Nikulina T., Mandelshtam M., Petrov A., Nazarenko V., Yunakov N. 2015. A survey of the weevils of Ukraine. Bark and ambrosia beetles (Coleoptera: Curculionidae: Platypodinae and Scolytinae). Monograph // Zootaxa. Vol.3912. No.1. 61 pp.

Petrov A.V. 2013. [New data and synonymy of Scolytus Geoffroy, 1762 (Coleoptera: Curculionidae: Scolytinae) from Russia and adjacent countries] // Lesnoy Vestnik. No.6(98). P.39-47 [in Russian].

Petrov A.V., Dostavalov E.A. 2015. [Change of aggressiveness of the bark beetles (Coleoptera: Curculionidae: Scolytinae) associated with pathogenic microorganisms] // Izvestiya Sankt-Peterburgskoy Lesotekhnicheskoy Akademii. Vol.211. P.76-91 [in Russian]

Pfeffer A. 1995. Zentral- und Westpaläarktische Borken- und Kernkäfer (Coleoptera: Scolytidae, Platypodidae) // Entomologica Basiliensia. Bd.17. S.5-310.

Schedl K.E. 1948. Bestimmungstabellen der Palaearktischen Borkenkäfer, Teil III. Die Gattung Scolytus Geoffr. // Zentralblatt für das Gesamtgebiet der Entomologie. Monographie. Nr.1. 67 S.

Smith S.M., Hulcr J. 2015. Scolytus and other economically important bark and ambrosia beetles // Vega F.E., Hofstetter R.W. (eds.). Bark beetles. Biology and ecology of native and invasive species. Academic Press. P.495-524.

Sokanovskiy B.V. 1954. [Notes on bark beetles of the fauna of USSR] // Byulleten' Moskovskogo Obshchestva Ispytateley Prirody. Vol.59. No.5. P.13-22 [in Russian].

Sokanovskiy B.V. 1958. [Notes on Coleopera, Ipidae in the fauna of the USSR] // Byulleten' Moskovskogo Obshchestva Ispytateley Prirody. Vol.63. No.5. P.37-40 [in Russian].

Sokanovskiy B.V. 1960. [On the taxonomy and distribution of bark beetles (Coleoptera, Ipidae) in the USSR and adjacent countries] // Entomologicheskoe Obozrenie Vol.39. No.3. P.674-678 [in Russian].

Sokanovskiy B.V. 1966. [Key for the determination of species from USSR belonging to the genus Scolytus Geoffroy] // Acta Entomologica Bohemoslovaca. Vol.63. No.5. P.380-393 [in Russian].

Spessivtsev P.S. 1925. [Key to bark beetles of the most important tree species in the European part of the USSR]. Moskva-Leningrad. 87 pp. [In Russian]

Stark V.N. 1952. [Bark beetles] // Fauna SSSR. Zhestkokrylye. Vol.31. Moscow-Leningrad: Izdatel'stvo Akademii Nauk SSSR. 462 pp. [In Russian]

Wood S.L., Bright D.E. 1992. A Catalog of Scolytidae and Platypodidae (Coleoptera), Part 2: Taxonomic Index // Great Basin Naturalist Memoirs. Vol.13(A). P.1-833. 